\title{
Evaluation of Ecological Design Principles in Traditional Houses in Mersin
}

\author{
Ebubekir Gündoğdu1 ${ }^{1}$, Emel Birer ${ }^{2} \odot$ \\ ${ }^{1}$ M.Arch., Faculty of Architecture, İstanbul Kültür University, İstanbul, Turkey. (Principal contact for editorial \\ correspondence), Email: gundogdue@gmail.com \\ ${ }^{2}$ Prof.Dr., Faculty of Architecture, İstanbul Kültür University, İstanbul, Turkey. Email: emelbirer@gmail.com
}

\begin{abstract} Purpose

Advances in technology and rapidly developing built environment lead to increased energy consumption and depletion of natural resources while harming the environment. The concept of ecological architecture emerged to generate solutions to these problems and various characteristics of traditional architecture, such as use of local and natural materials, energy saving etc. became important for contemporary ecological architecture. This paper addresses, from an ecological perspective, vernacular traditional architecture in Mersin, which has rapidly grown into a metropole from a 19th century Mediterranean port town. This study focuses on the ecological design components among traditional Mersin houses. The objective of this study is to reveal the relationships between vernacular traditional houses of Mersin and ecological architecture and to serve as a guide and reference for architects to design and construct in a way that they do not harm the natural environment and ecological balance by learning from vernacular architecture.

Design/Methodology/Approach

For the case study, 30 traditional houses located in Mersin old city centre, have been chosen to be inspected in terms of storey height, structural system, materials used for the construction, roof shape and materials, topography, selection of orientation, vegetation pattern, building form, spatial organisation, building envelope, use of renewable energy sources, sanitary installation and circulation systems. Yes and no scaled checklists were used to assess 30 traditional houses to identify the components of their ecological status and the quantitative data drawn from these checklists were used for the analyses of the urban texture.

Findings

It is observable from the analysis that traditional vernacular architecture of Mersin has various qualities that are compatible with ecological design criteria of our day.

\section{Research Limitations/Implications}

30 traditional houses which have not been restored, have been chosen in Mersin old city centre.

Originality/Value

The results presented in charts and diagrams are aimed to serve as design recommendations in today's architectural practice in the area and as an ecological pattern in sustainable development projects performed in the future.
\end{abstract}

Keywords: Vernacular architecture, ecological design, Mersin traditional houses, ecology and architecture 


\section{INTRODUCTION}

The industrial revolution and ensuing technological developments resulted in architectural characteristics, such as proportion, scale, construction practices, materials and locality that ensure ecofriendliness, being overlooked. Certain characteristics of traditional architecture highlighting environmental soundness, use of local and natural materials, harmony with topography, energy efficiency seem to take a backseat in today's architecture. Structures emerging today are disconnected from locality, harmful to their surroundings and the environment, high-energy consumers. Ecological Architecture approach is a system of thought, which argues that buildings should not be designed solely based on functional and aesthetic concerns by questioning production techniques and design criteria used for today's structures, that is environmentally friendly, and aims to protect habitats and natural resources.

Vernacular architecture has already achieved the ecologic solutions required for living comfort; moreover, current ecological discourses in sustainable housing have already been adopted in the typology of the traditional dwellings (Kırbaş and Hızlı, 2016). The features of the traditional architecture such as environment friendliness, use of local and natural materials, respecting the topography and focusing on energy-saving seem to remain in the background in the contemporary architecture. The construction sector, including housing, comprises 30 to $40 \%$ of the world's total energy demand and approximately $44 \%$ of total material use (Li, 2006). Similarly, greenhouse gases causing global warming result mostly from the construction sector (Sayı, 2006). Therefore, ecological building design has recently gained importance. The numbers of ecological designs in the world has been increasing rapidly. In parallel to this increase, in Turkey, especially universities start several applications on this matter. In Turkey, ecological buildings that have different usage areas, different numbers of floors and different functions are being designed starting from 1980 up to our day (Gültekin and Bengü, 2011). The ecological, spatial and sociocultural sustainability of traditional settlements will be ensured by spanning the planning and design processes on ecological basis and the application of nature friendly design approaches (Erdoğan and Yıldız, 2017).

Founded as a harbour on the Mediterranean coast in early 19th century, Mersin was transformed into a metropole in early 20th century. Such rapid growth resulted in Mersin's traditional architecture being pushed aside and a multitude of rapidly produced and consumed structures. Majority of these buildings are designed and built as structures that are disconnected from locality, with high-energy consumption and with sole concern around aesthetics and revenue. This study aims to show the relationship between eco-architecture and vernacular architecture based on an analysis of the examples of traditional architecture in Mersin from an ecological point of view. It is emphasized that ecological 
data of Mersin traditional architecture may provide an insight for new eco-friendly housing ideas in the future.

\section{ECOLOGICAL DESIGN PRINCIPLES}

Human beings, a part of nature themselves, started to flex their muscles on nature and use up what the nature offered them selfishly and without restraint, having been strengthened by technological advances and mechanisation. This has disturbed the balance of the environment in which we live and caused irreversible destruction over time. However, it is the natural right of all living beings to live in a healthy environment. On the protection of environment, the article 56 of the Constitution of the Republic of Turkey stipulates that, "Everyone has the right to live in a healthy and balanced environment. It is the duty of the State and citizens to improve the natural environment, to protect the environmental health and to prevent environmental provision" (URL 1).

High on the global agenda, environmental pollution necessitated the emergence of a new understanding considering not only today's needs but also those of future generations over time. Concept of ecoarchitecture has developed as a result of this understanding. Krusche, Gabriel and Althaus (1982) sum up key points to consider in ecological designs as follows:

- $\quad$ Positioning buildings with a rational approach to environmental and energy-related matters, building design approaches, building form, building design organisation, organisation of spatial schemes and functions, selection of materials, sanitary system installations and designing fit-for-purpose green vegetation,

- $\quad$ Minimising the use of energy and scarce resources during both the construction and use of the building,

- Rational use of natural environmental systems (taking advantage of solar power, natural air conditioning and green vegetation)

- Minimising the pollution of soil and water basins that are contaminated by thermal, liquid and solid waste,

- $\quad$ Protecting fauna and flora potential in the region, and increasing them in number and variety,

- $\quad$ Placing the building with minimum damage possible to the natural environment to create a healthy residential and work environment (Tönük, 2001).

Ecological design is sustainable systems, consistent with ecological principles, which integrate human society with its natural environment for the benefit of both. In many ways, the environmental crisis is a design crisis. It is a consequence of how things are made, buildings are constructed, and landscapes are used. We have used design cleverly in the service of narrowly defined human interests but have neglected its relationship with our fellow creatures. We will all have to create new lives based on ecological design principles (Van Der Ryn and Stuart, 1996). 
Ecological design principles comprise multi-faceted and variable components depending on the baseline situation. Although it is said that there is no definitive model for design criteria to be used to understand eco-architecture, most researchers emphasize the need to identify some criteria (Lyle, 1985). In this context, the guiding criteria in compliance with the principles of eco-architecture may possibly be grouped under two categories, namely, settlement and design criteria (Table 1).

Table 1. Ecological Design Criteria (Lyle, 1985)

\begin{tabular}{|l|l|}
\hline \multicolumn{1}{|c|}{ Settlement Criteria } & \multicolumn{1}{c|}{ Design Criteria } \\
\hline Land Data & Building Form \\
\hline Topography & Spatial Organisation \\
\hline Selection of Orientation & Building Envelope \\
\hline Vegetation Pattern & Selection of Materials \\
\hline Climate Data & Use of Renewable Energy Sources \\
\hline & Sanitary Installation and Circulation Systems \\
\hline
\end{tabular}

Settlement criteria comprise land data, topography, selection of orientation, vegetation pattern and climate data, whereas design criteria comprise building form, spatial organisation, building envelope, selection of materials, use of renewable energy sources as well as sanitary installation and circulation systems. A building's integration with environment primarily involves the consideration of some features like topography and climate. Rational use of these environmental systems which minimize negative effects on ecosystem, leads to the physical environmental components of ecological architecture (Crowther, 1992). Features such as building properties, compatibility with buildings' environment, use of material, heating and cooling systems are the factors affecting building energy consumption. From this point of view, traditional buildings are built with the surrounding material, adapting to the local climatic conditions, so they are healthy and have high sustainability. It is possible to learn how to use energy most efficiently from traditional houses (Karahan and Ergöz, 2017; Sanchez and Medrano, 2015). When the traditional architecture examples are analyzed, it is seen that the ecological approach, has been adopted in these examples in advance and balanced solutions have been reached with the environment and climate in this context. (Şen, etc., 2010; Zorlu and Faiz, 2012).

\section{VERNACULAR ARCHITECTURE IN MERSIN}

Mersin is located between $36-37^{\circ}$ north altitude and $33-35^{\circ}$ east longitude. Mersin portrays all typical characteristics of Mediterranean climate and meteorological conditions.

\section{Climatic Data}

Mersin has all the typical features and meteorological conditions of the Mediterranean climate. The Mediterranean climate is hot and dry in the summer, warm and rainy in the winter. The average annual temperature in Mersin is $18.7^{\circ} \mathrm{C}$. The average temperature of summer months varies 
between $25-33^{\circ} \mathrm{C}$. Low temperatures of up to $10^{\circ} \mathrm{C}$ are observed in the interior and upland skirts. In winter, the average temperature varies between $9-15{ }^{\circ} \mathrm{C}$. Snowfall is not seen in coastal areas. However, during the winter months, varying amounts of snowfall occur in the foothills and plateaus of the Taurus Mountains. The total amount of annual precipitation is $593.7 \mathrm{~mm}$. Most precipitation is in December and the least is in August. Most of the year the weather is clear and little cloudy (Ministry of Environment and Urbanization Mersin Reports, 20112012).

\section{Topography}

Mersin province area is located on the Western and Central Taurus Mountains. The Taurus Mountains, which fall into the provincial borders, lies between the Konya plain of Central Anatolia and the Mediterranean as a high-roofed belt in the West-East direction. Considering the overall geomorphological state of the province; wide plateau plains, Mediterranean coastal belts and wide plains and valleys around the Göksu River. The valleys stretching from south to north are inserted into the Taurus Mountains. The landforms and physical geography of the region are plains and valleys in the coastal region, plateaus and hills in the middle zone and mountainous areas in the highlands. The physical geography of the region is an important factor affecting microclimate, climate, vegetation, settlement pattern, distribution of population and economic activities.

Figure 1. Inclination status of Mersin province. (Mersin Metropolitan Municipality, 2011)

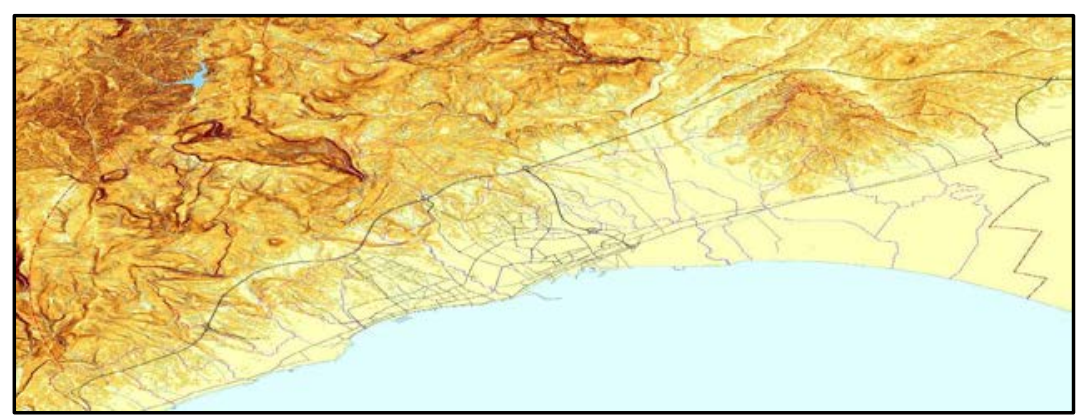

\section{Climate}

Mersin has more than 300 sunny days per year. If we group them according to the amount of sun rays Turkey receives, Mersin has the same values as Adana, Gaziantep, Diyarbakır and Şanlıurfa in the first zone district (Buldum and Külekçi). (Table 2 ) 
Table 2. Climatic Data of Mersin Province (Source: URL2)

\begin{tabular}{|c|c|c|c|c|c|c|c|c|c|c|c|c|c|}
\hline & 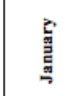 & 롤 & $\frac{5}{5}$ & 蒄 & 商 & $\stackrel{g}{g}$ & 常 & 蓄 & 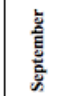 & 起 & 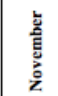 & 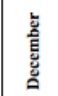 & 可 \\
\hline & \multicolumn{13}{|c|}{\begin{tabular}{|l|} 
Measurement Period $(1940$ - 2019) \\
\end{tabular}} \\
\hline $\begin{array}{l}\text { Mean } \\
\text { Temperature }\left(^{\circ}\right. \\
\text { C) }\end{array}$ & 10,1 & 11,0 & 13,7 & 17,4 & 21,2 & 25,0 & 27,7 & 28,3 & 25,7 & 21,4 & 16,1 & 11,8 & 19,1 \\
\hline $\begin{array}{l}\text { Highest Mean } \\
\text { Temperature } \\
\left({ }^{\circ} \mathrm{C}\right)\end{array}$ & 14,5 & 15,4 & 18,1 & 21,6 & 24,9 & 28,1 & 30,7 & 31,5 & 30,0 & 26,6 & 21,5 & 16,4 & 23,3 \\
\hline $\begin{array}{l}\text { Highest Mean } \\
\text { Temperature } \\
\left({ }^{\circ} \mathrm{C}\right)\end{array}$ & 6,2 & 6,8 & 9,1 & 12,8 & 16,8 & 20,8 & 23,9 & 24,2 & 20,8 & 16,2 & 11,5 & 7,8 & 14,7 \\
\hline \begin{tabular}{l|} 
Mean \\
Sunshine \\
Duration \\
(hour) \\
\end{tabular} & 4,7 & 5,6 & 6,7 & 7,6 & 8,4 & 9,8 & 9,9 & 9,8 & 9,1 & 7,5 & 5,7 & 4,7 & 89,5 \\
\hline $\begin{array}{l}\text { Mean Number } \\
\text { of Rainy Days }\end{array}$ & 10,6 & 9,2 & 7,6 & 6,7 & 5,1 & 2,2 & 0,9 & 0,8 & 1,7 & 5,0 & 6,6 & 10,4 & 66,8 \\
\hline \multirow{2}{*}{$\begin{array}{l}\text { Mean Monthly } \\
\text { Precipitation ( } \\
\text { man) }\end{array}$} & 118,5 & 85,5 & 56,2 & 34,8 & 23,8 & 10,2 & 11,6 & 6,9 & 11,7 & 39,2 & 77,8 & 139,6 & 615,8 \\
\hline & \multicolumn{13}{|c|}{ Measurement Period (1940 - 2019) } \\
\hline $\begin{array}{l}\text { Highest } \\
\text { Temperature } \\
\left({ }^{\circ} \mathrm{C}\right)\end{array}$ & 25,2 & 26,5 & 29,8 & 34,7 & 36,0 & 40,0 & 38,1 & 39,8 & 39,0 & 37,5 & 31,0 & 27,0 & 40,0 \\
\hline $\begin{array}{l}\text { Lowest } \\
\text { Temperature } \\
\left({ }^{\circ} \mathrm{C}\right)\end{array}$ & $-6,3$ & $-6,6$ & $-2,2$ & 0,6 & 7,0 & 12,0 & 16,1 & 15,0 & 11,0 & 2,7 & $-3,3$ & $-3,0$ & $-6,6$ \\
\hline \multicolumn{2}{|c|}{$\begin{array}{l}\text { Highest Daily Total } \\
\text { Precipitation }\end{array}$} & \multicolumn{2}{|c|}{ Fastest Wind Force } & \multicolumn{2}{|c|}{ Highest Snow Depth } & & & & & & & & \\
\hline 26.12 .1968 & $199.5 \mathrm{~mm}$ & 7.02 .2003 & \begin{tabular}{|l|}
123.1 \\
$\mathrm{~km} / \mathrm{sa}$
\end{tabular} & 13.01.1950 & $2.0 \mathrm{~cm}$ & & & & & & & & \\
\hline
\end{tabular}

Mersin is one of the cities which have Turkey's highest sunshine duration. Sunshine duration is 7.4 hours per day and in the summer period; it varies between 8-10 hours. The dominant wind direction in Mersin is northwest, but this situation varies according to the months and seasons during the year. Winter and spring (except May), the dominant wind direction is north-northwest in a six-months, whereas in summer (May, June, July and August) dominant wind direction is southsouthwest. Strong winds are effective in the south and southwest directions in the city center. According to 2011 data in the city center, the average wind speed is $1.51 \mathrm{~m} / \mathrm{s}$ per year. MGM states the highest value of wind speed as $123 \mathrm{~km} / \mathrm{h}$ measured in February. Long-term and strong winds are generally in the south-southwest direction in winter and spring. (Ministry of Environment and Urbanization Mersin EIA reports, 2011-2012)

The average pressure in Mersin varies within months. In the summer, the city is under the influence of Basra's low pressure, and it receives arid and rare precipitation. During the winter months, Mersin is usually under the influence of low pressure from the Middle Mediterranean.

\section{TRADITIONAL SETTLEMENT IN MERSIN}

Mersin's first emergence as a harbour and then as a city was influenced by changing functions and characteristics of Çukurova cities in the early 19th century (Ünlü, 2009). Enjoying uninterrupted settlement since antiquity, the city of Tarsus was one of the most important settlements of Cilicia up until early $19^{\text {th }}$ century due to its close proximity to important trade and caravan routes and its location as a safe inland port (Akkaya, 2004). Mersin developed as a harbour that accelerated the transition of the region into high-capacity commercial agriculture and 
helped Çukurova to establish its identity as the most important cotton producer and exporter of the Ottoman Empire (Toksöz, 2006). As in many other harbours, cosmopolitism comprising migrants and the Levantines proved a significant feature of the urban demography in Mersin (Adıyeke and Adıyeke, 2004). Another component influencing the city's development and physical formation was the shifting relationship of transportation and product flows. Far-reaching effects of the Suez Canal on the region and Mersin were marked since the construction of the former, increasing Mersin's significance (Develi, 2001). One of the first neighbourhoods of the city cited in the archival records of the 19th century is Cami-i Şerif Neighbourhood, which still stands today (TȘS, No: 318, s.365, h.no: 625, 25 Cemazeyilevvel 1298). The urban fabric starting with the triangle of Gümrük Square, Yoğurt Market and Uray Street and forming Cami-i Șerif Neighbourhood seem to have expanded to include Frenk Neighbourhood, Kiremithane, Bahçe, Mahmudiye, Mesudiye, İhsaniye (Giritli), Osmaniye and Medrese (present day Hamidiye) Neighbourhoods due to growing population (Ünlü, 2009). Formation and development of neighbourhoods in the city were due to religious, cultural and political influences. This is one of the most important characteristics of Mersin that sets it apart from the traditional Ottoman city. Given the development of the city, particularly after 1980's, it can be said that urban development took place under pressures from rapid population growth and intense migration (Mediterranean Urban Research Centre Report,2005).

Traditional houses of Mersin bear different characteristics to the known traditional vernacular architecture in nearby cities in terms of the period in which they were built. Administrative innovations introduced by the Ottoman Empire in the 19th century and changes in people's lifestyles greatly influenced the way the architecture was shaped. The variety of domestic architecture in Mersin reflects the social and economic background of their owners. According to the plan of a house, one can determine from which region of the Empire the owner migrated to Mersin (Yenişehirlioğu, Özveren and Ünlü, 2019). The city, formed by a cosmopolitan community with its members coming from different countries and regions, was brought together as a blend of many factors including climate, economy and culture. Traditional Mersin houses, which have no separate spatial compartments such as Harem and Selamlik, usually have façades and openings directly overlooking the street. With clear-cut and right-angled plan drawings, these houses have lines running parallel to streets and façades formed with a symmetrical, simple and straight geometry. They usually have one or two floors, most of which are built with cut-stones while first floors or projections are sometimes built with bagdadi (timber frame and infill construction) technique. Majority of these houses built with cut-stones have gardens or exterior porches on the upper floor, overlooking the north or the east. This is how the open space ensuring airflow into the house is protected against the scorching sun and seaward winds from the south or the 
west. In houses with external sofas, garden is larger than closed spaces of the house. Most of the daily life is spent in these gardens, which house the lodge and the pool. Louvered shutters made of wood are used for the ventilation of homes in traditional Mersin houses in order to prevent visual access from outside. Mersin houses have their unique, different and advanced aspects unlike the classical Ottoman housing typology. In terms of plan typology, there are many variations as "Pike", "Interior hall", "Exterior hall" and "Eclectic" (Yenişehirlioğlu, Müderrisoğlu \& Alp, 1965).

Façades may differ as street walls and sidewalls. Street-facing walls are decorated with some architectural elements and ornaments. Sidewalls are built in a leaner manner. The building system is generally detached housing. Eaves were generally not used in Mersin houses. Roofs are built with wooden materials and covered with Marseille roof tiles. Entrances are categorised as ground floor entrance and upper floor entrance. Upper floor entrances of these mostly two-storey vernacular houses are built sometimes on the side facade and sometimes on and symmetrical to the street facade, which is also the ground floor entrance. Ground floor entrances directly open up to the street from the road front. Direct linkage of living spaces in the house with both the street and the inner courtyard showcases that two different concepts, namely, consistency of cohabitation and protection of house privacy run parallel (Dizdar, 2009). Located on vertical axis, windows lend a lean appearance to the façade, having been placed rhythmically and regularly on a horizontal axis. Windows allowing light into sofas or the stairwell leading to the sofa in houses with internal sofas are peculiar to Mersin vernacular. Windows are built double sash and parts of double sash windows that are above the lintel work independently from the bottom part, ensuring ventilation from the upper part. Houses have wooden louvered shutters covering windows to keep the indoors from being visible while ensuring ventilation (Yenişehirlioğlu, 2005).

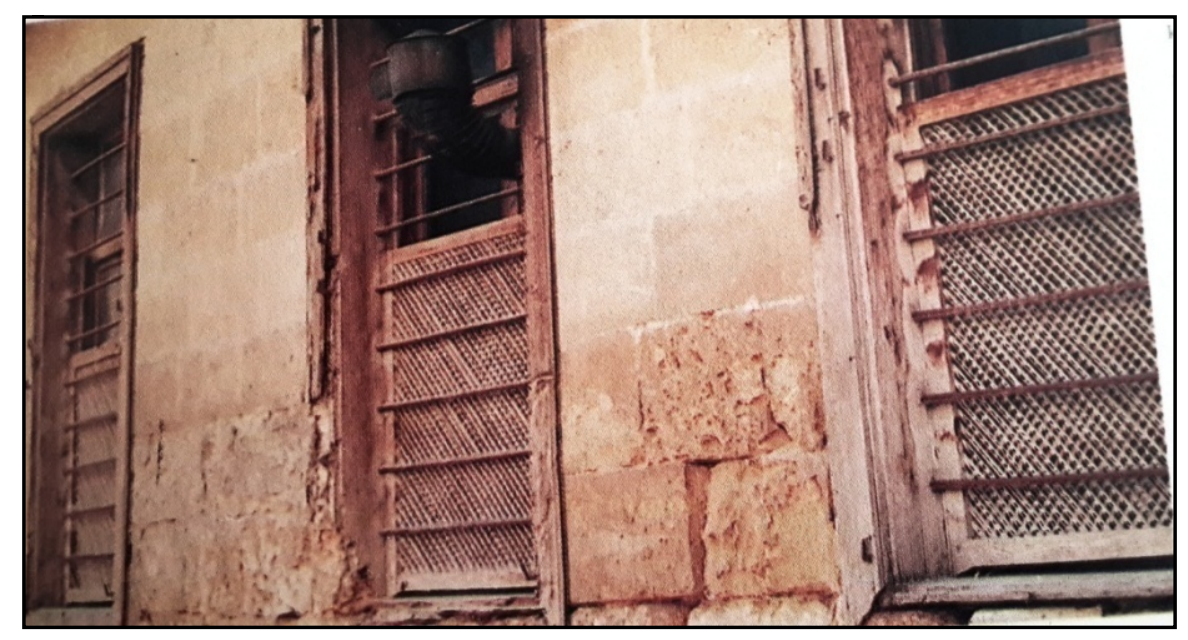

Figure 2. Shutter Example (Fatih Müderrisoğlu)

Windows are made with a biplane, and the parts on the lintel above the 
two-leaf windows can work separately from the bottom to provide ventilation from the top (Figure 3-4-5-6). There are shutters made of wood covering the windows to prevent the visibility of the interior while ensuring the ventilation of the houses. Depending on the climate, other features such as wide overhangs, airlock entries, arcades or porches, atria and natural ventilation may boost the building's efficiency (Oktay, 2002). To render shutters adjustable according to the arrival of the light, the wing of the shutter consists of two separate parts and can be doubled vertically. Sometimes, in two-winged shutters, the types of shutters are made, where the lower part of the shutter opens up without folding the shutter. Shutter is mostly seen in houses with external sofas in ground floor windows (Figure 2). They are formed by frequent nailing of wooden slats. Such shutters can slide from the bottom of the window to the top.
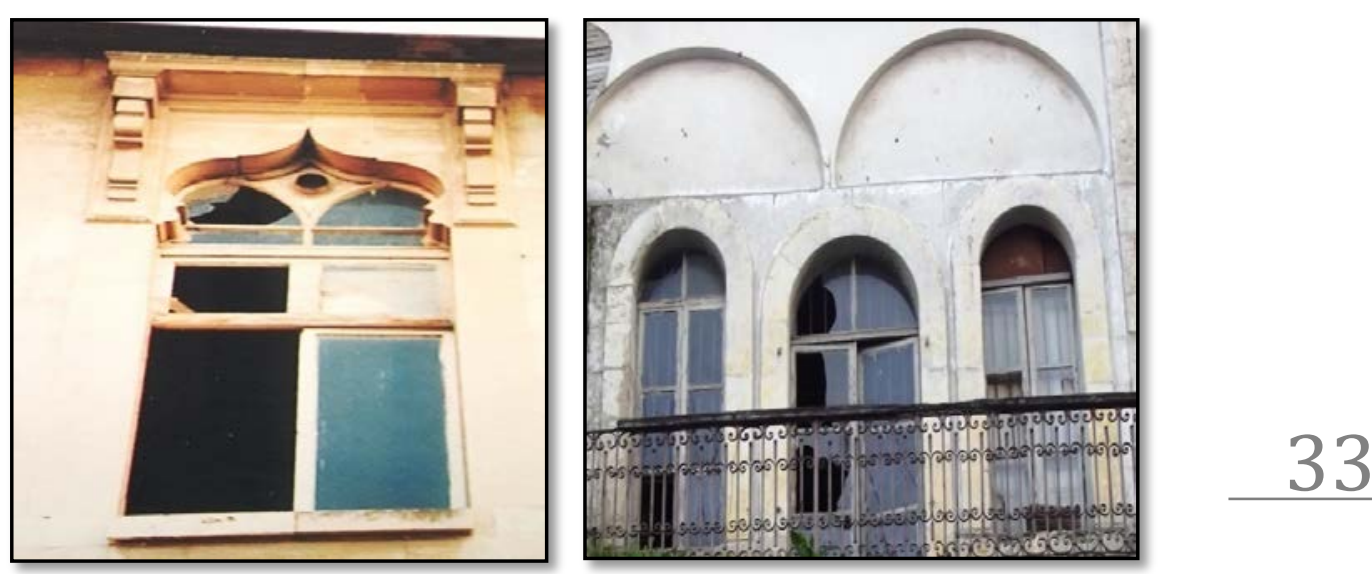

Figure 3-4-5-6. Window Samples of Mersin Traditional Houses (Ebubekir Gündoğdu)
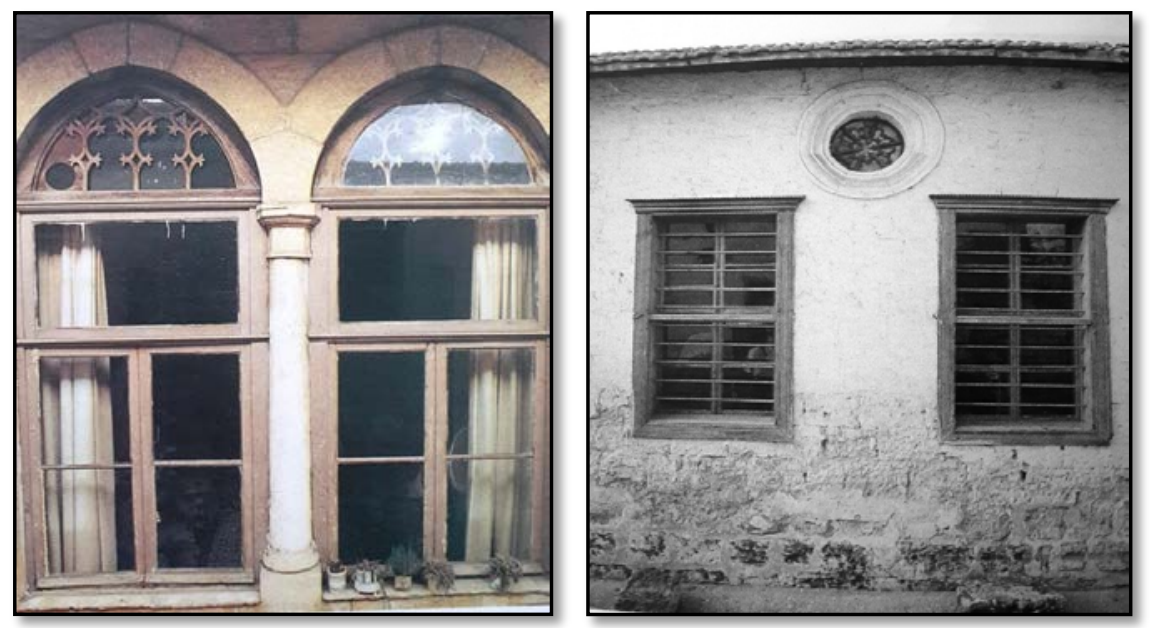

Mersin houses developed differently from classical Ottoman vernacular typology, with their original and distinctive aspects. Eclectic houses of European families residing in Ottoman cities due to trade relations. One of the most important reasons for the development of this style is that the architecture in the XIX. century was not realised by the Ottoman central palace and state organisations but by independent architects (Yenişehirlioğlu, 2004). 


\section{METHODOLOGY}

This study focuses on the ecological design among traditional Mersin houses and their settlement criteria (topography, orientation and green texture) and design criteria (building form, space organization, building envelope, choice of materials, use of renewable energy sources, sanitary and circulatory systems). In this context, 30 vernacular structures that have not been renovated were selected from this area of the city centre, where 129 out of 220 registered immovable cultural assets are located and where there is still strong presence of traditional vernacular fabric, to identify ecological characteristics of Mersin traditional vernaculars. (Figure 8) For an ecological assessment of traditional vernaculars, binary checklists were prepared on yes and no scale, in line with the guiding criteria for housing design complying with the principles of ecological architecture. The selected houses were inspected in accordance with these checklists. Analytic data was produced with the figures drawn from these checklists to display the percentages of ecologic compatibility among the selection.

\section{Research Area}

Research area covers the zone surrounded by İsmet İnönü Boulevard in the south, $5113^{\text {th }}$ Street in the north, the Orthodox Church in the east and Tevfik Sirrı Gür High School in the west. (Figure 7) Atatürk Park is located in the south of the area and Republic Area is in the west. The fact that the important commercial and administrative centers of the city are located within the area causes the intensity of pedestrian and vehicle traffic throughout the area. The part of the south of Istiklal Street, which developed as the administrative and commercial center of the city in the historical period, is an important administrative and commercial center of the city today. There are mostly residential buildings in the region located in the north of İstasyon Avenue. The majority of the traditional buildings in the area consist of two-storey buildings.

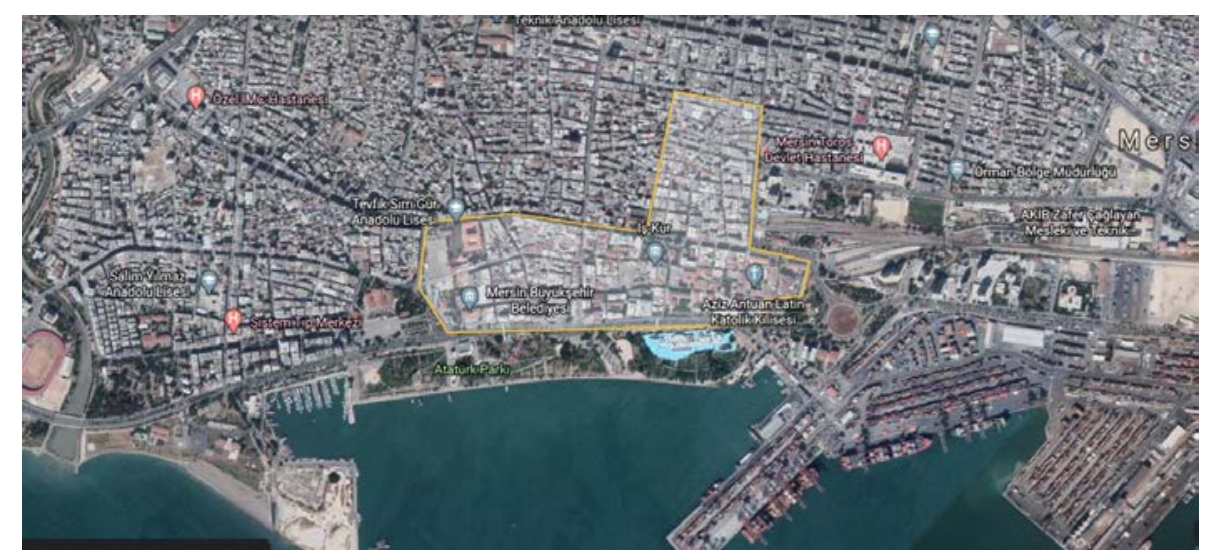


Evaluation of Ecological Design Principles in Traditional Houses in Mersin

\section{ECOLOGICAL DESIGN STRATEGIES IN MERSIN TRADITIONAL HOUSES}

The evaluation of vernacular architecture is a mean to comprehend significant element of their environment and construction (Gunewardene 2016). It is hoped that this analysis will give architects a general understanding of the ecological value of the traditional heritage and will contribute to the search for a more sustainable method of development (Baran, Yıldırım and Yılmaz, 2011) Given that both heritage and sustainability are two crucial facts for societies, continuity of original features should be ensured in a historical site, design features should be transferred to future generations and sustainability should be supported as yet another critical objective (Kaptanoğlu and Mıhçığlu Bilgi, 2018). As a consequence of this opinion 30 traditional Mersin houses are evaluated from their settlement criteria and design criteria by their checklists.

Figure 8. Traditional Houses of Mersin under Study (Authors' Archive)

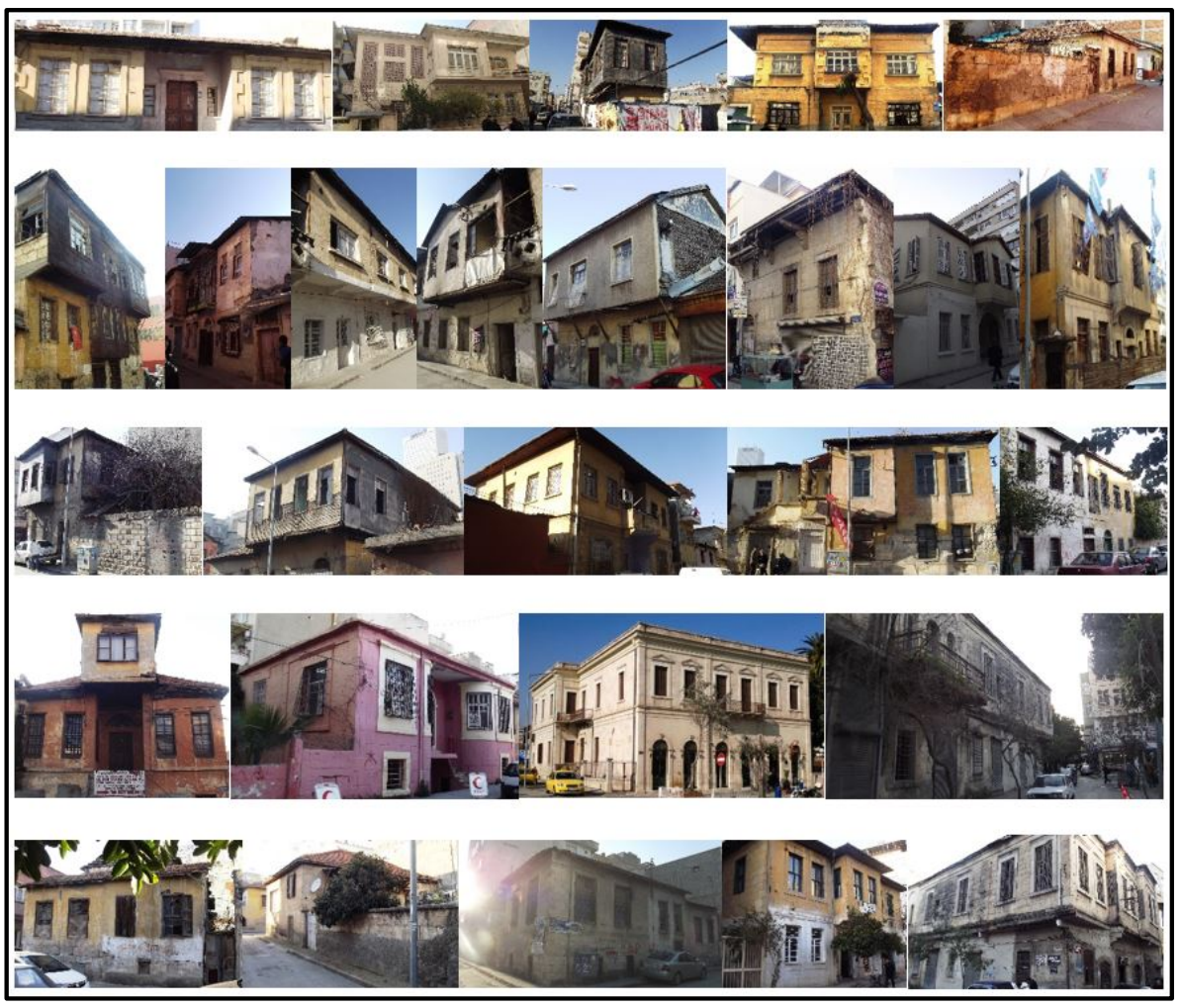

The guiding criteria cover the location, architectural features, structural condition, ownership status, usage status, photographs, sketch and some drawings of the structure on checklists (Table 3) Storey height, structural system, materials used for the construction, roof shape and roof materials of the structure were also studied. Settlement criteria were examined under three categories; namely: topography, selection of orientation, vegetation pattern. Design criteria were examined under six categories; namely: building form, spatial organisation, building envelope, selection of materials, use of renewable energy sources, sanitary installation and circulation systems. 
Table 3. Ecological Assessment Checklist

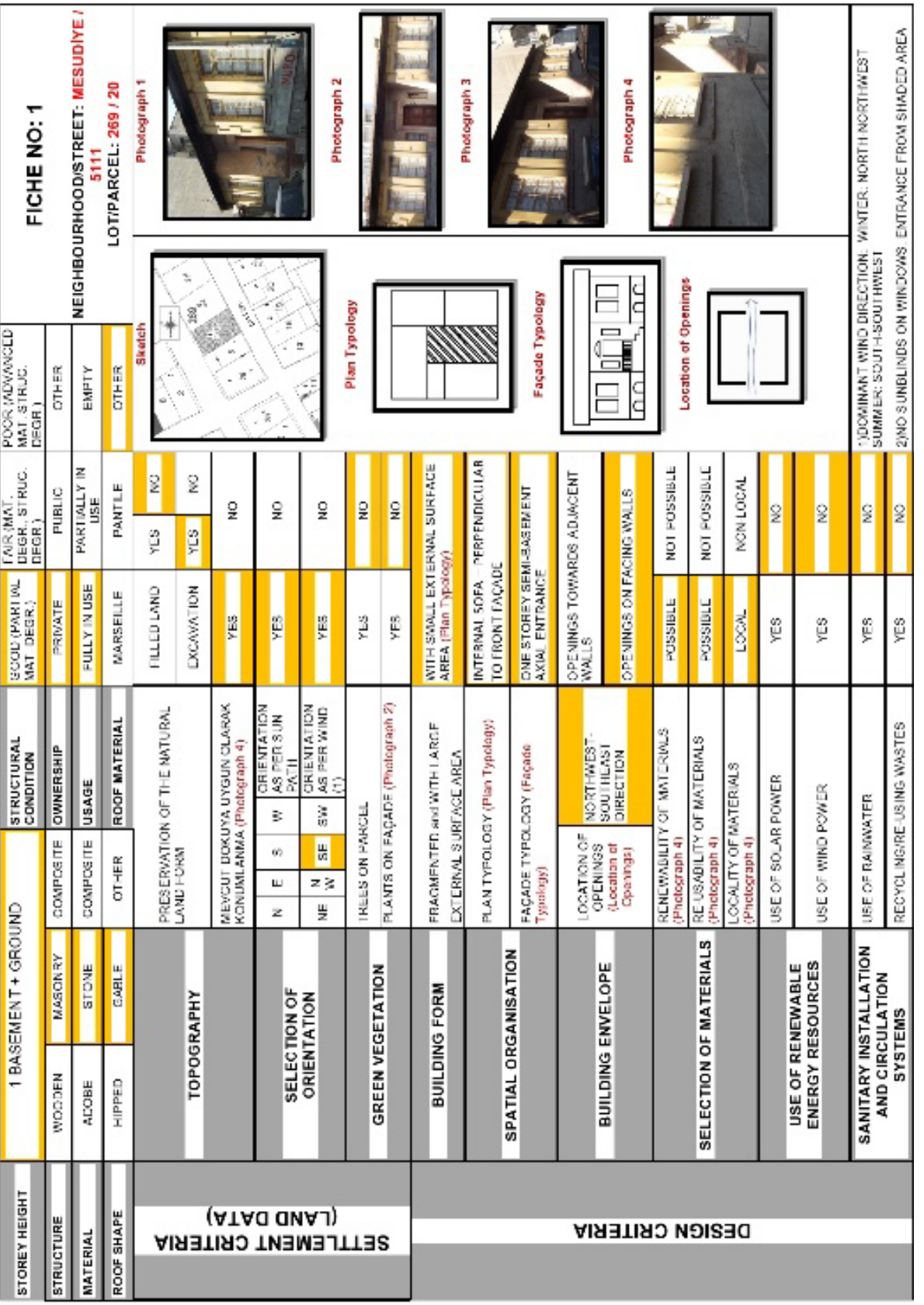

Floor height of structure was defined for each structure while studying in the area. Structural systems were classified as wood, masonry construction and wood-masonry (the last will be referred to as composite construction within the text from this point on). Materials used in the construction of the structure were classified as brick, stone and brick-stone. While roof shapes were pitched roof, gable roof and other, roofing was analysed as Marseille tiles, squat tiles and other. Structural condition is evaluated as good where structures have partial material degradation; as fine where structures have material and structural degradation; as poor where structures have advanced material and structural degradation. Property status was analysed as private, public and other, and usage was analysed as totally, partly and 
vacant house. Settlement criteria were analysed under three titles as topography, direction selection and green texture. Topography was analysed under 2 titles as the protection of the natural form of the land and proper positioning of the texture. Under the title of "Protection of the natural form of the land", it was analysed whether the landfill or excavation process was in place on the existing topography during the positioning of the building. Under the title of "Proper positioning of the texture", it was analysed whether the positioning of the building was made according to the structure of the street and terrain textures. In the selection of the direction, the orientation of the structure was analysed according to the sun and the dominant wind conditions. Under the title of "Green texture", it was analysed whether the vegetation was used or not in the parcel and facade of the building.
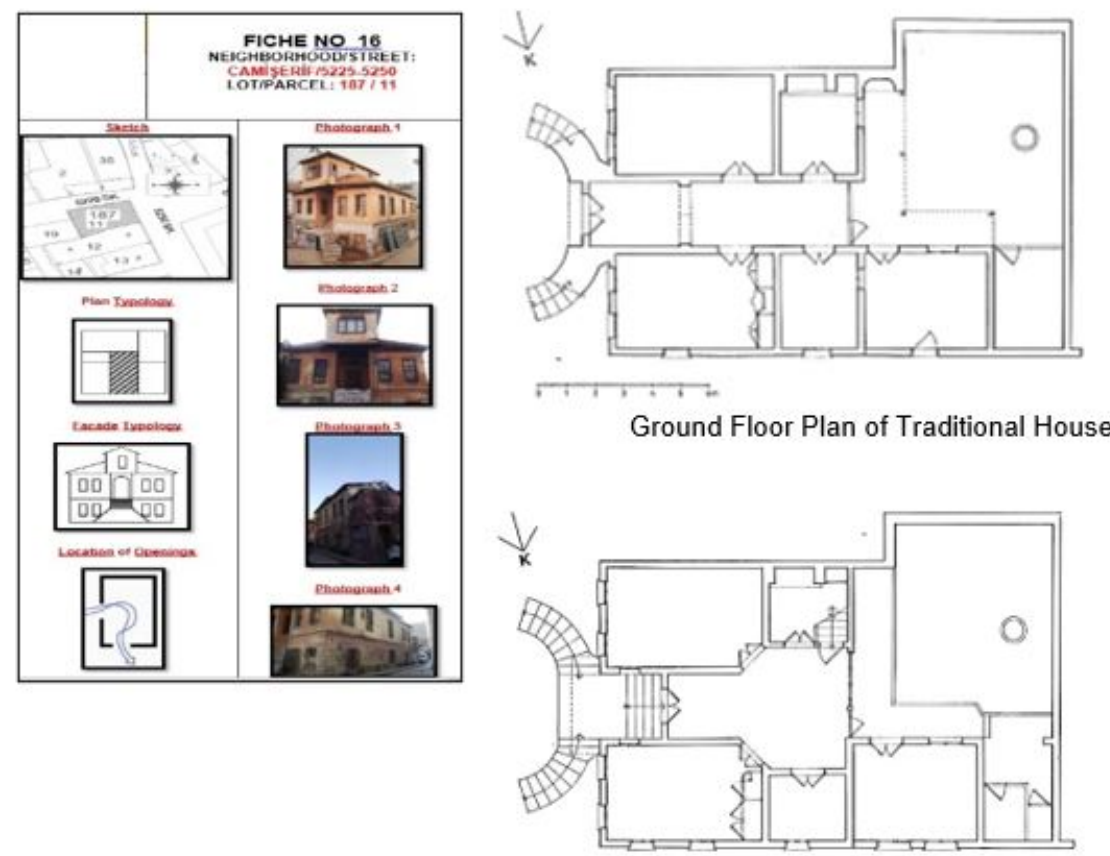

Figure 9. Sample 1 Traditional House of Mersin under Study (Yenișehirlioğlu, F., Müderrisoğlu, F. S. Alp, (1965) "Mersin Evleri" is taken as a source for plans and inside photos)
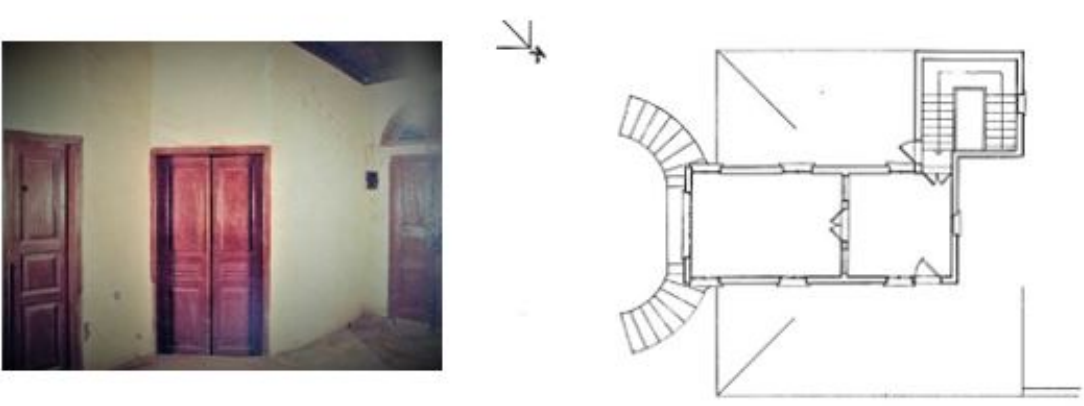

Inside Photo of Traditional House

Second Floor Plan of Traditional House 
Design criteria were analysed under six titles as building form, space organization, building envelope, choice of materials, use of renewable energy sources, sanitary and circulatory systems. Building forms in ecological design and surface area are important criteria for determining the building's heat retention. Therefore, building forms were studied under two titles as fragmented and large external surface area of the building form and small external surface area of the building forms. Large external surface area of buildings form: Construction of the buildings with wider fragmented and exterior space in order to increase the possible heat loss on the surfaces in hot climates. Small external surface area of the building form: Construction of the buildings with narrower fragmented and exterior space in order to prevent the possible heat loss on the surfaces in cold climates. Location organization was studied under two titles as plan and front typology.
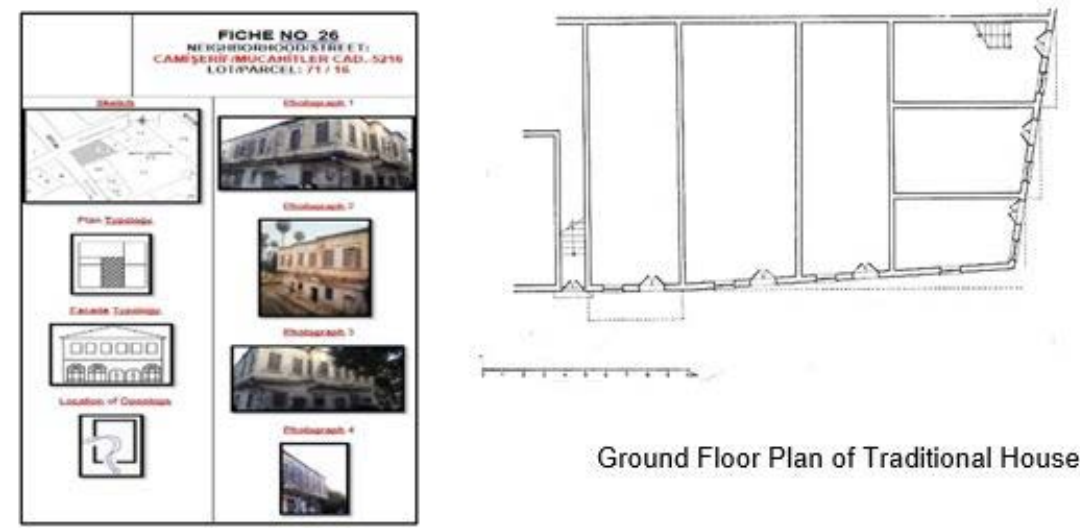

Ground Floor Plan of Traditional House
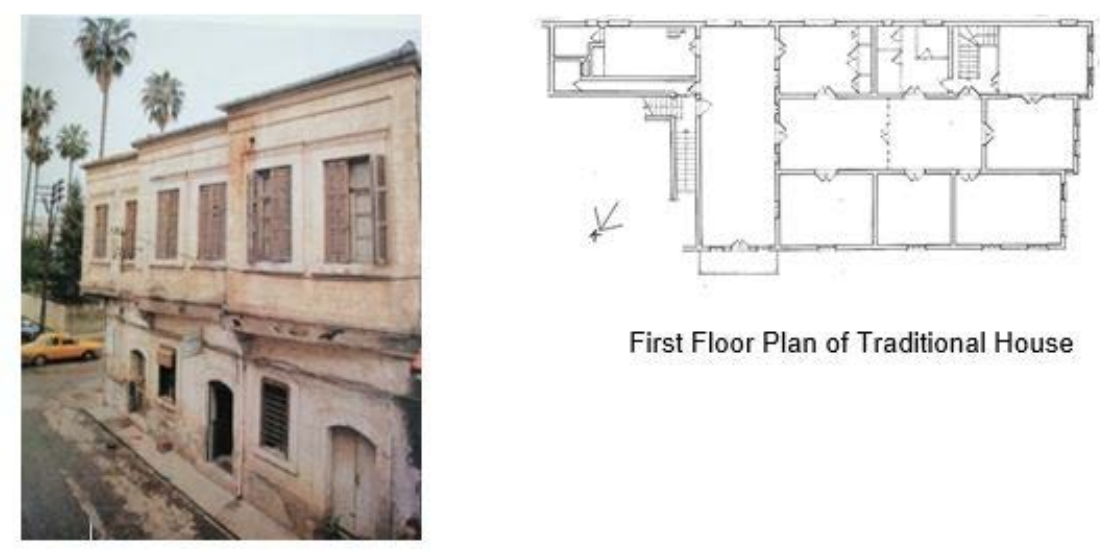

First Floor Plan of Traditional House

Photo of Traditional House
Figure 10. Sample 2 Traditional House of Mersin under Study (Yenișehirlioğlu, F., Müderrisoğlu, F. S. Alp, (1965) "Mersin Evleri" is taken as a source for plans and inside photos)

Plan typology is an important criterion in terms of heating, cooling and natural ventilation methods of structures. Location organization should be constructed so that ventilation can be made and the heat in the house can be reduced easily. It is important to heat the building in cold climates, thus spaces producing heat such as the kitchen should be constructed in the centre of the structure. Front building typology in the natural ventilation and air circulation structure is associated with the occupancy and space in front of the building. Moreover, the movements 
on the facade of the structure will change the surface area and thus the structure will be affected from the outside air much.

Building envelope was analysed under two titles as spaces opened to adjacent wall and spaces opened to opposite walls. The rate and location of the spaces for doors and windows opened on the building envelope determine the heat loss and gain of the building as well as the comfort conditions of the indoor area.

There are examples of different plan schemes in the residential buildings within the research area. Apart from houses with a planning scheme, there are also structures with different plan features. It is the most common type of interior plan that we encounter. The ground floors of the buildings whose upper floors are arranged as residences are frequently located in the area in the examples used as warehouses or shops. In terms of spaces opening to adjacent walls, it is important to ventilate the constructions using natural methods especially in hot and hot-humid climates. Therefore, the decision where to place a certain space in the building should be given attention to ensure the efficiency of the natural ventilation. Placing the window on the opposite side of the surface of the facade towards the air intake direction will provide highspeed close airflow. If the window is placed in the opposite direction and the direction of the wind, the airflow is provided through the interior space. Spaces opened to opposite walls: airflow rate inside the building can be provided by opening the spares for windows and doors on the opposite sides.

Material selection has been analysed under three titles as locality of material, recyclability of the material and the material reusability. In terms of the locality of the material, materials that require less energy in the production and transportation phases, damage the nature less should be used in ecological designs. In terms of recyclability of the material, materials should be chosen as the least damaging the nature during construction usage and demolishment phases, and they should be reusable after the demolishment of the building. In terms of the reusability of the material, reusable recyclable materials reduce the consumption of natural resources. The use of local material can be considered as an ecological challenge. Since local materials are abundant, reusable and recyclable, they have a low impact on the environment and cause a cash flow within the community (Karahan and Davardoust, 2020). These features should be taken into consideration in the material selection. 

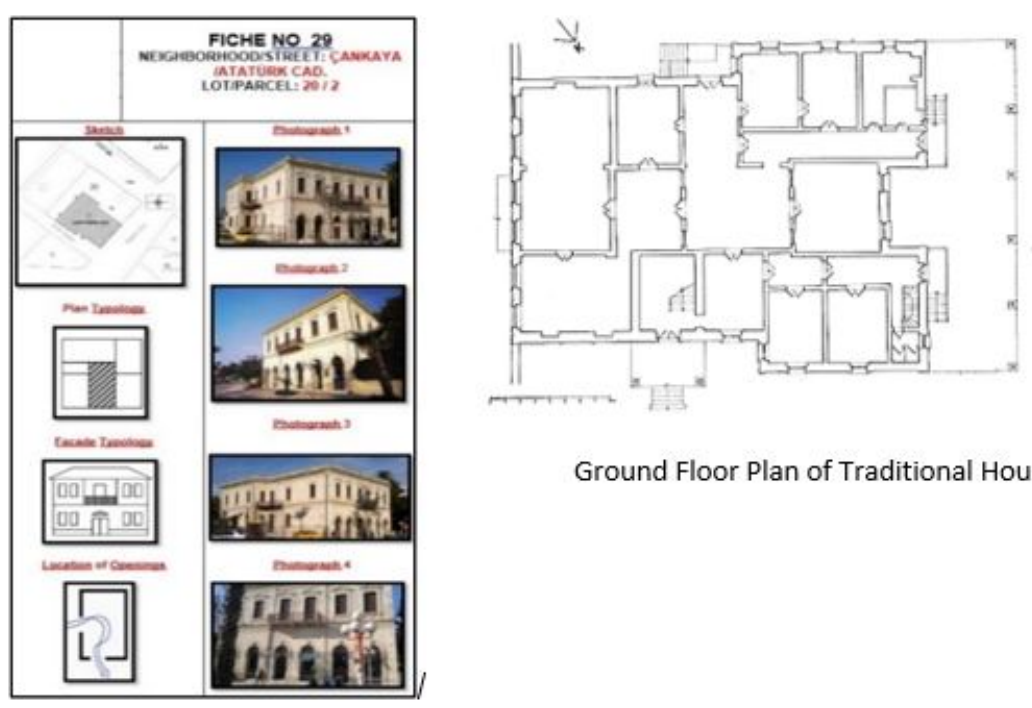

Ground Floor Plan of Traditional House
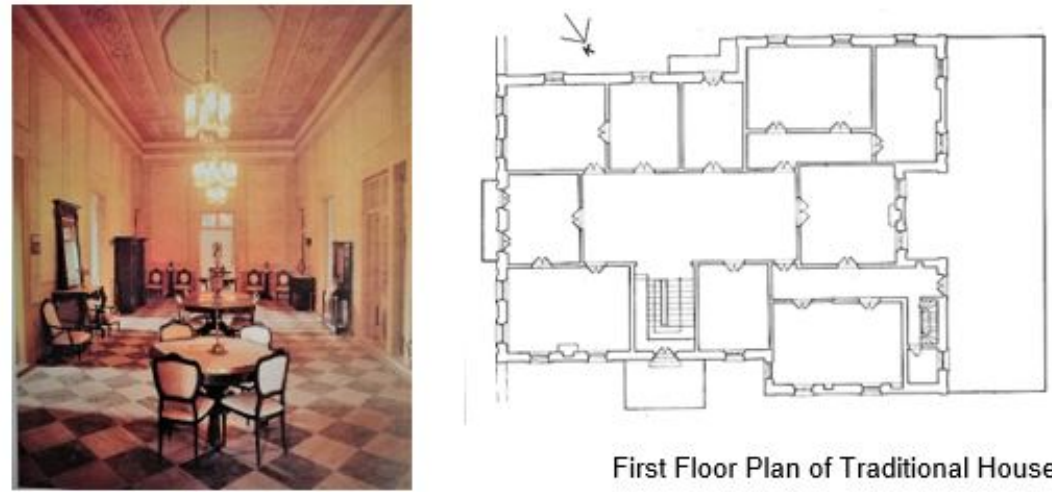

First Floor Plan of Traditional House

Inside Photo of Traditional House

Figure 11. Sample 3 Traditional House of Mersin under Study (Yenişehirlioğlu, F., Müderrisoğlu, F. S. Alp, (1965) "Mersin Evleri" is taken as a source for plans and inside photos)

The use of renewable energy sources has been analysed under two titles as benefit from solar energy and wind energy. To benefit from wind energy, air movement is required in hot-humid climate regions in terms of the ventilation of the interior. Air currents between the courtyard and the building occurring by means of natural convection in hot-dry climates are achieved by means of wind pressure in warm-humid climate regions. Plumbing and circulation systems were analysed under two titles as the use of rainwater and the recycling and reuse of waste. In terms of the ecological approach of recycling and reuse of waste, waste is provided for usage as raw materials after being processed. Therefore, the recycling or use of waste that arise during the use of the structure is quite important. In terms of the use of rainwater, collection and reuse of the rainwater is one of the precautions that can reduce the risk of the exhaustion of the water in the world. 
Evaluation of Ecological Design Principles in Traditional Houses in Mersin
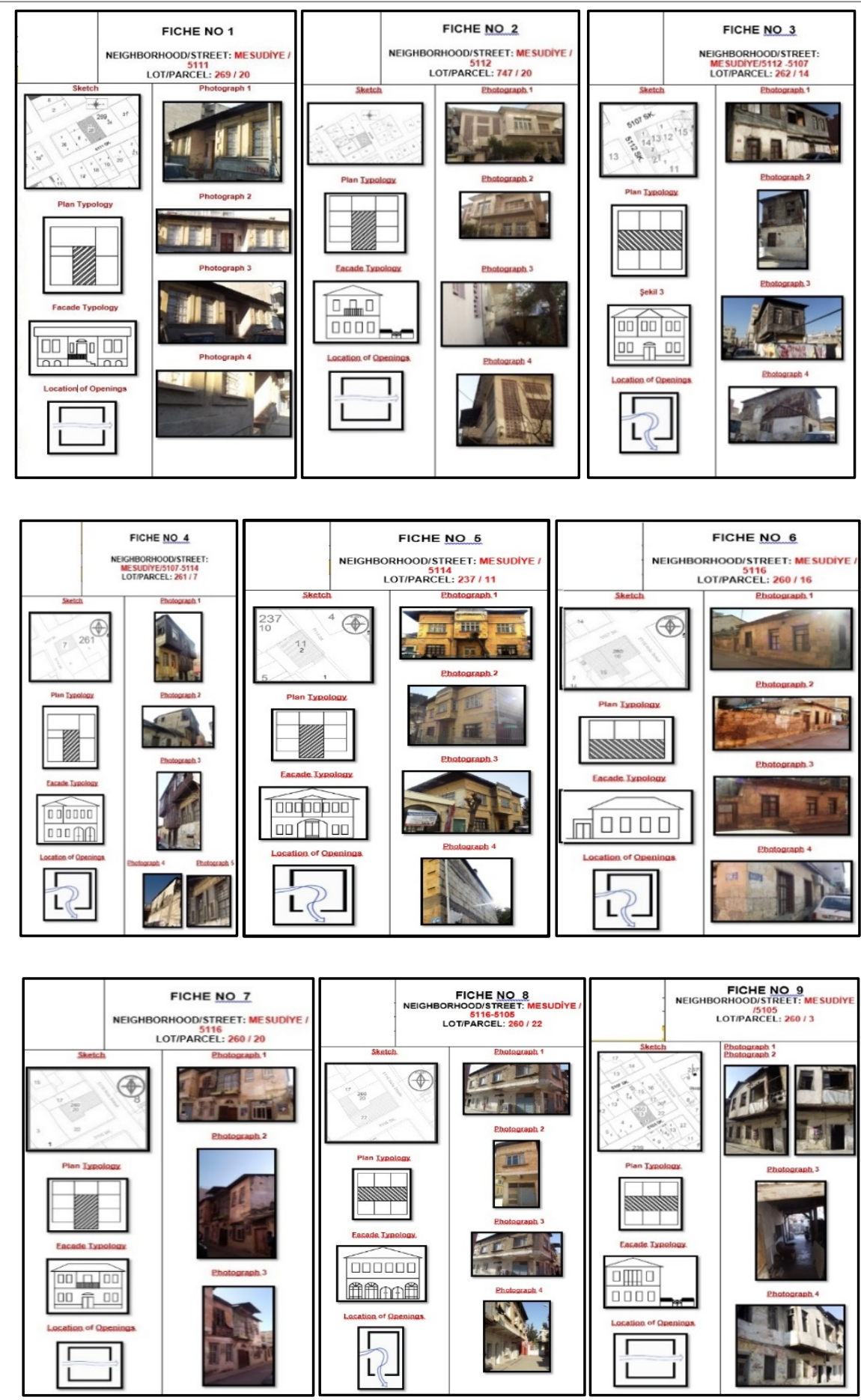

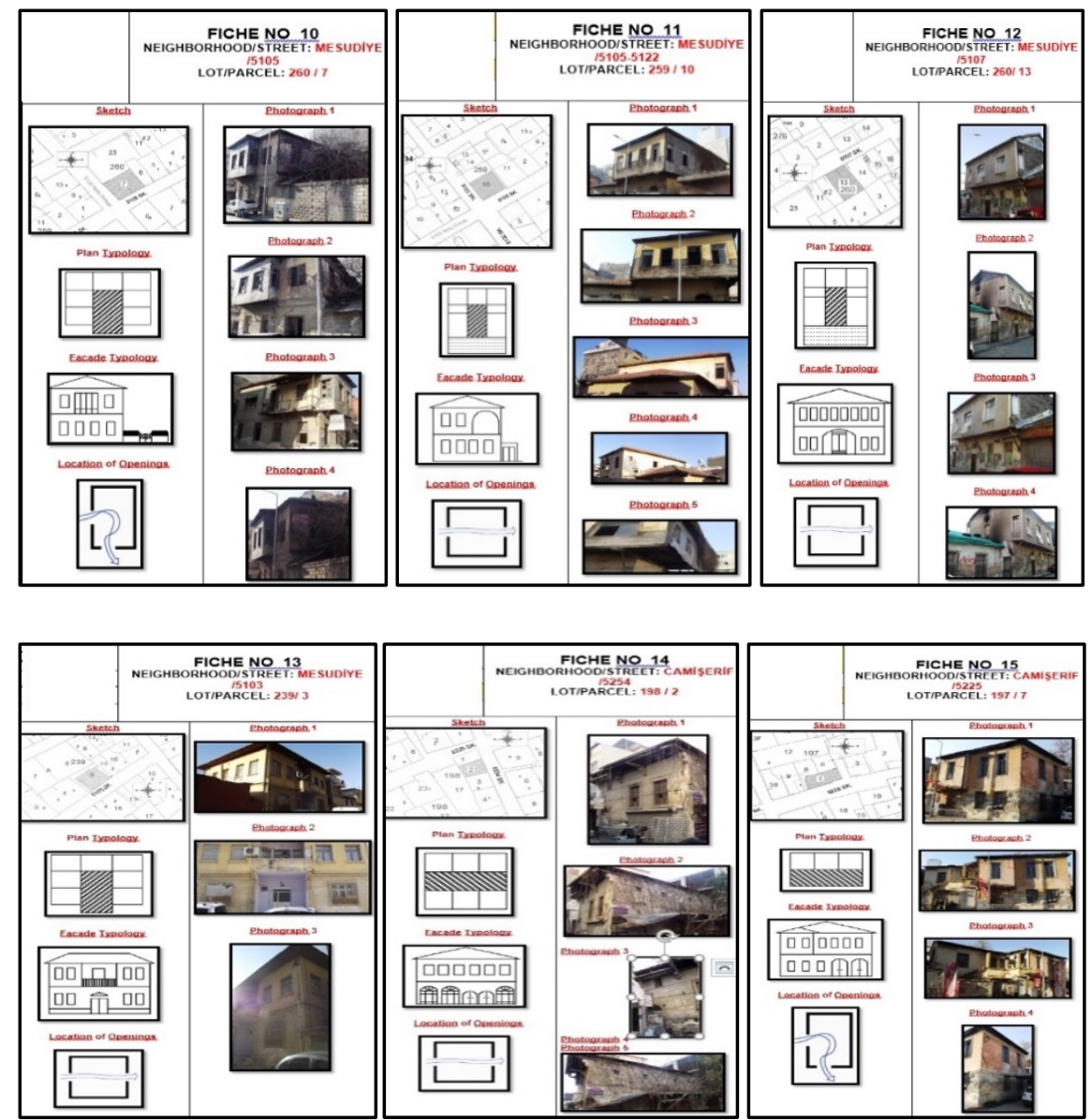

42
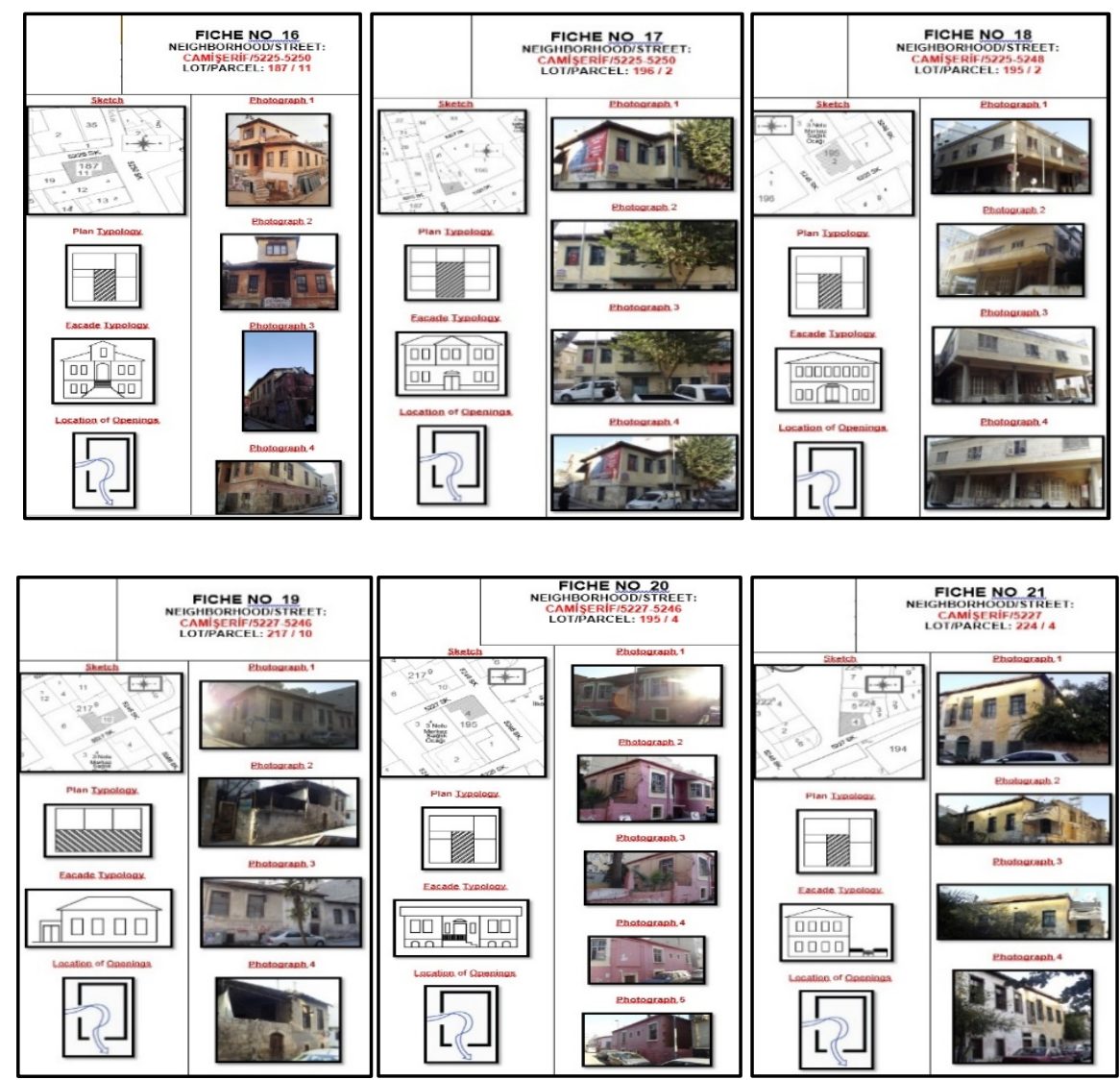
Evaluation of Ecological Design Principles in Traditional Houses in Mersin
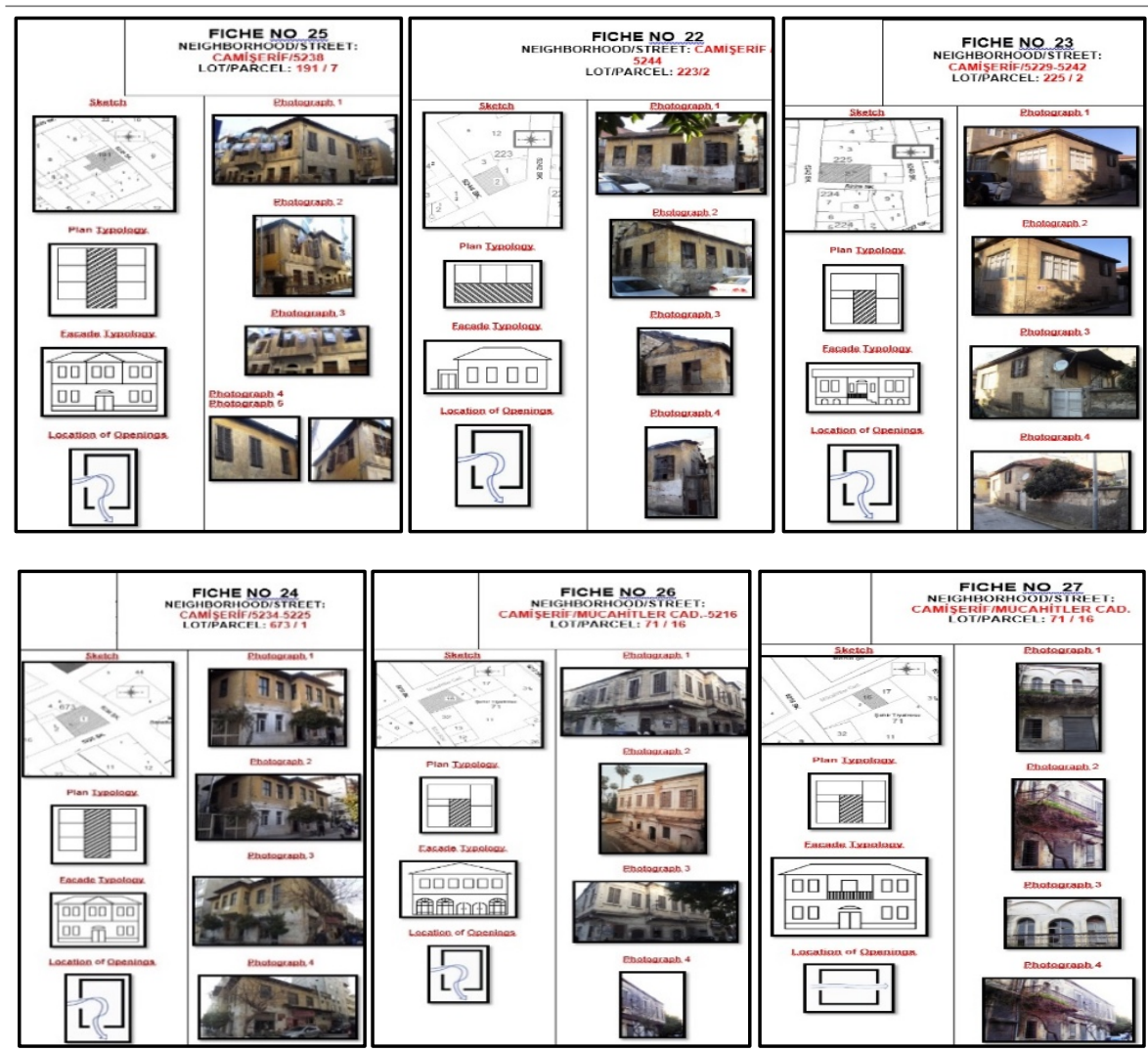

Figure 12. Sections from Fiches of 30 Traditional Houses

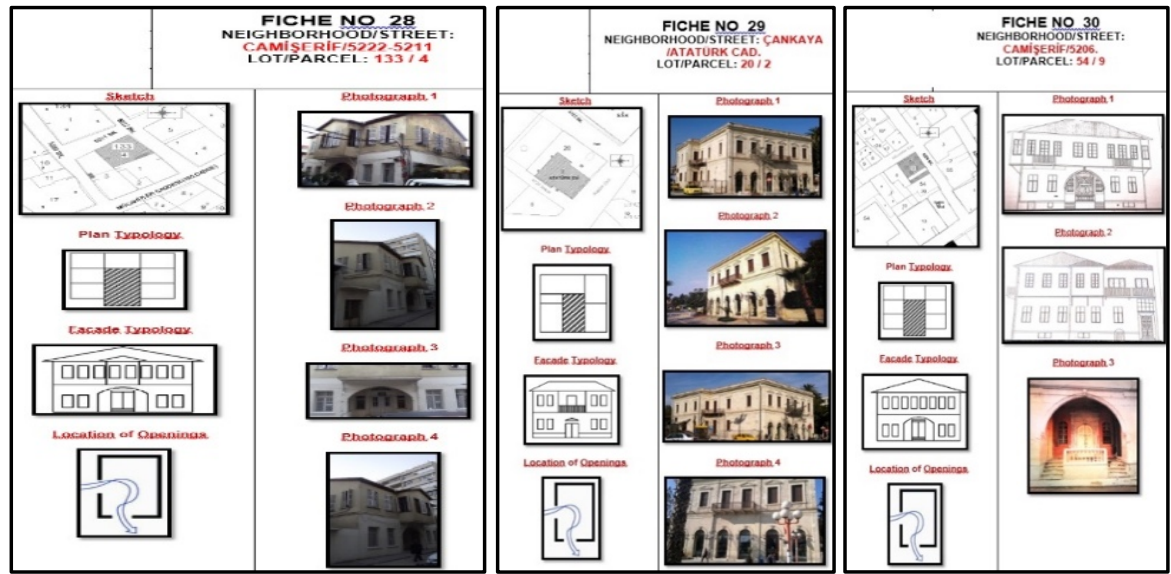

FINDINGS AND DISCUSSION

The following findings were made based on the 30 structures studied within the identified area (Figure 9-10-11-12).

\section{Storey Height}

Out of a total of 30 buildings under examination, 1 building comprised ground floor (3\%), 5 buildings comprised 1 basement and ground floor (17\%), 20 buildings comprised ground floor and 1 normal storey (67\%), 4 buildings comprised 1 basement, ground floor and 1 normal storey $13 \%$ (Figure 13). In terms of thermal mass and surface to volume ratio, low-rise buildings are considered to be energy efficient and therefore environment friendly (Mazouz, Zoulala, 2013). According to these findings, traditional Mersin houses maintain their connection to the 
nature and the environment because they have few storeys, which makes them ecological from this point of view.

\section{Structural Condition}

Structural condition of all 30 buildings under examination: 10 in good condition (with partial degradation of materials) (34\%), 13 in fair condition (with material and structural degradation) (43\%), seven in poor condition (with advanced material and structural degradation) (23\%). (Figure 13) It is significant from the viewpoint of their sustainability that the buildings are in good and fair condition to a large extent.

\section{Structural System}

Examination of all 30 buildings in terms of their structural systems revealed that 19 were of masonry (63\%) and 11 were of composite (37\%) structure. (Figure 13) No building with wooden structure was encountered.

\section{Ownership Status}

Ownership status of all 30 buildings in the study was as follows: 28 private property (93\%), 1 public property (4\%), 1 other (3\%). (Figure 13)

\section{Material State}

State of materials in all 30 buildings under examination was identified as follows: 17 buildings with stone (57\%), 13 buildings with composite materials (43\%). (Figure 13) No adobe brick materials were found in buildings under examination. The fact that the majority of materials used in the buildings were stone and composite show that they were built from natural materials. Stone structures are ecological for they help cool down inner spaces in summer while keeping them warm in winter. Composite buildings made of stone and wood are ecological structures due to both stone with its natural insulation properties and wood, which is a living and breating material. These construction materials are considered to be environmentally conscious for they comply with the life cycle criterion that evaluates materials in terms of their effect on the environment throughout their different life stages (Bovea, M.D., Pérez-Belis, V., 2012). On the other hand, using vernacular materials require less energy consumption in the production, therefore these buildings are ecological (Chandel, S. S., Sharma, V., Marwah, B. M., 2016).

\section{State of Usage}

State of usage of all 30 buildings under examination: 13 buildings were fully in use (43\%), 2 buildings were partially in use (7\%), and 15 buildings were vacant (50\%). (Figure 13) The fact that $43 \%$ of buildings are fully and $7 \%$ are partially in use shows that the structures are 
Evaluation of Ecological Design Principles in Traditional Houses in Mersin

preserved, repaired and maintained regularly, and that life inside and around the buildings is sustainable.

\section{Shape of Roof}

Roof shapes of all 30 buildings were identified as follows: 8 pitched roofs (27\%), 21 gable roofs (70\%), 1 other (3\%). (Figure 13) Roof shapes of almost all of the buildings are either gable or pitched, which prevent excessive heating in summer and excessive cooling in winter. As roof shapes contribute to heating and cooling of buildings, they are ecological (Chandel, S. S., Sharma, V., Marwah, B. M., 2016).

\section{Roof Materials}

Out of all 30 buildings under examination, 27 had Marseille roof tiles (90\%), 3 had other roof materials (10\%) while no pantiles were found. (Figure 13) Having Marseille roof tiles, for being made out of clay, as roof materials is an ecological approach from recycling in terms of life cycle approach (Bovea, M.D., Pérez-Belis, V., 2012).

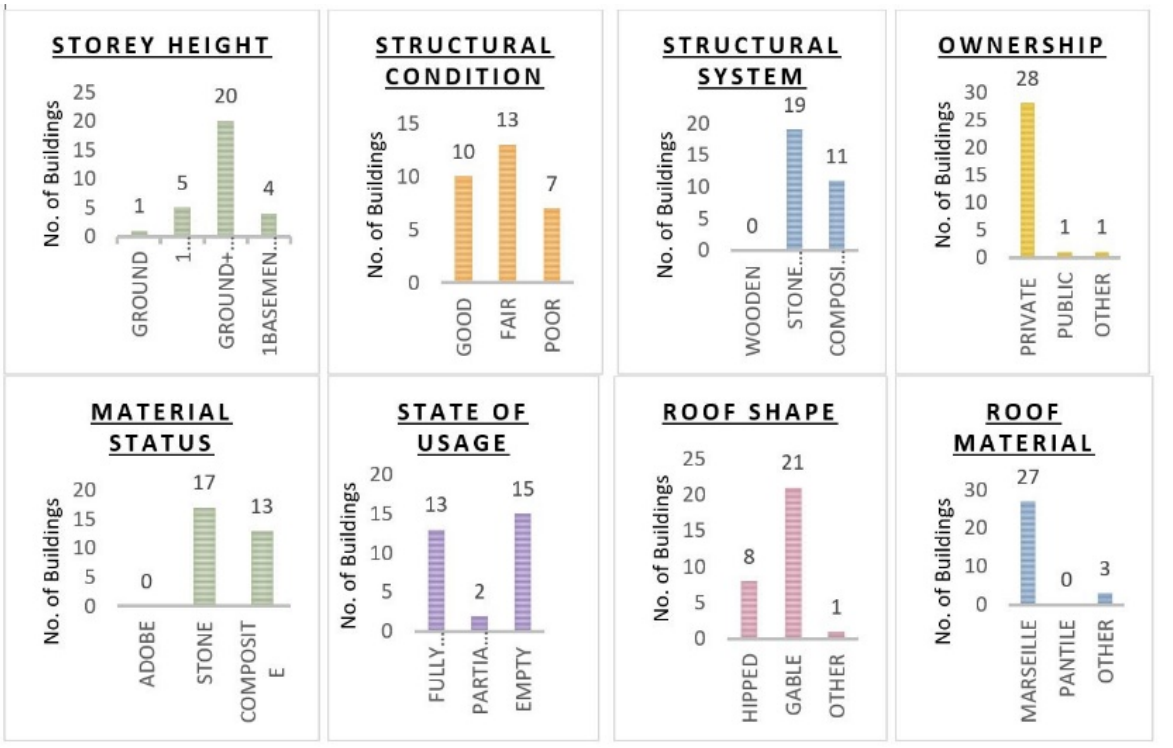

\section{Assessment of the Settlement Criteria}

All 30 buildings (100\%) were positioned in harmony with the existing fabric. From the viewpoint of preservation of the natural land form, none of the 30 buildings (100\%) were on filled land. 9 buildings required (30\%) excavation works. 21 buildings did not require (70\%) excavation works. (Table 5) According to present findings, vast majority of buildings are ecological because they did not intervene in the topography since "reduction of impact during use" is a significant ecodesign criterion (Vallet, F., Eynard, B., 2012).

\section{Selection of orientation}

Orientations of 30 buildings were as follows: 2 towards the west (7\%), 9 towards the northeast (30\%), 4 towards the northwest (13\%), 12 
towards the southeast (40\%) and 3 towards the southwest (10\%). 17 buildings were oriented (57\%) with respect to the sun path, 13 were not (43\%) oriented with respect to sun path. 12 buildings (40\%) were oriented with respect to dominant wind, $18(60 \%)$ were not oriented with respect to the dominant wind. (Figure 14) Positioning the masses in relation to the sun path and wind directions is an ecological approach for these passive climatization techniques reduce the need for external energy inputs which results is further consumption (Chandel, S. S., Sharma, V., Marwah, B. M., 2016) According to these findings, $57 \%$ of all buildings are ecological because they are oriented with respect to the sun path, and $40 \%$ are ecological because they are oriented with respect to the dominant wind.

\section{Vegetation pattern}

Out of all 30 buildings under examination, 19 (63\%) had trees in their parcels while $11(37 \%)$ did not. 4 buildings (13\%) had plants on their façades, 26 did not (87\%) have any plants on their façades. (Figure 14) As per these findings, the $63 \%$ which have plants in their parcels and the $13 \%$ which have plants on their façades are ecological.

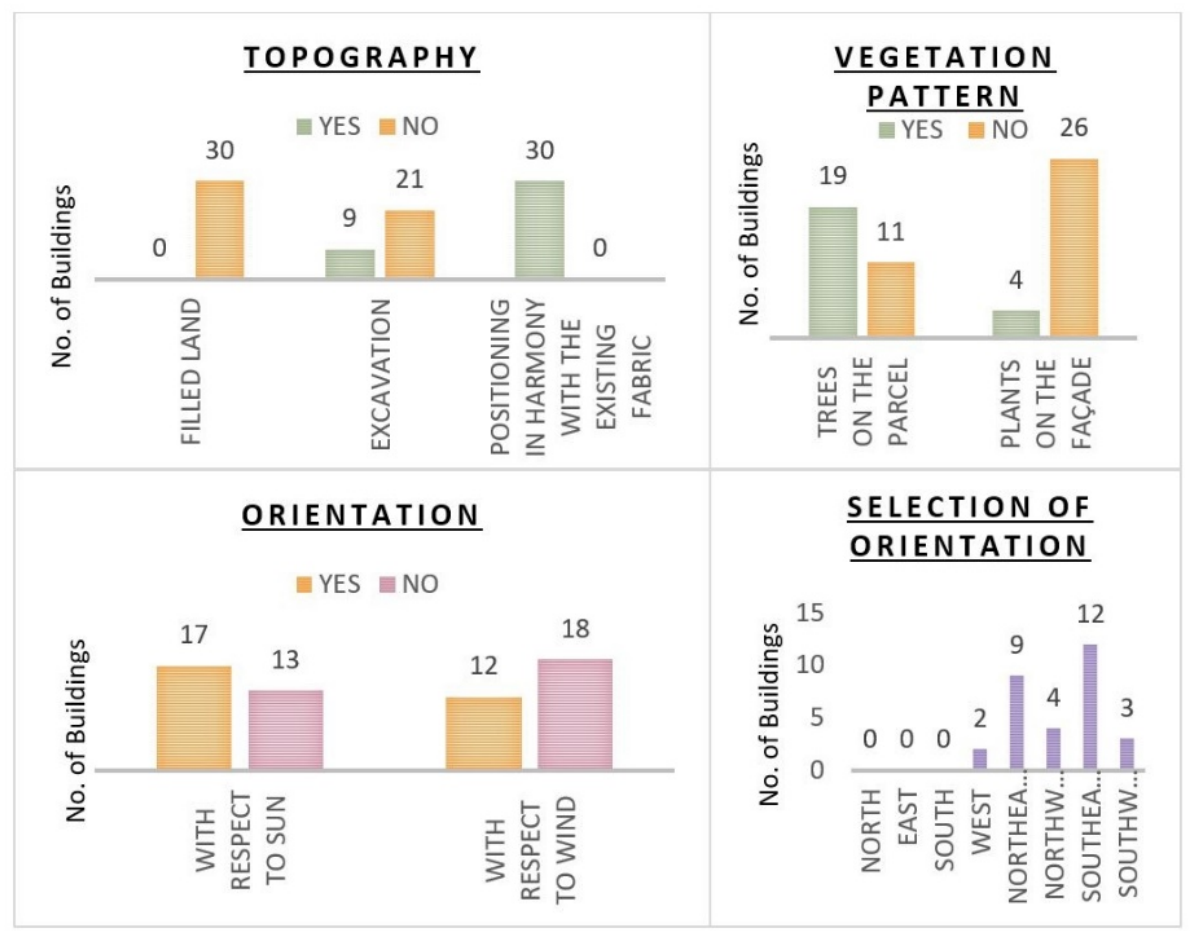

Figure 14. Findings

\section{Assessment of the Design Criteria Building form}

Form of all 30 buildings under examination was small building form with small external surface area. Since external surface areas of buildings are small and areas exposed to elements are limited, energy losses are also at a minimum. With regard to the relationship between 
Evaluation of Ecological Design Principles in Traditional Houses in Mersin

energy efficiency and building form, they are ecological (Mazouz, Zoulala, 2013).

\section{Spatial organisation}

All 30 buildings were identified in terms of spatial organisation as follows: 22 with (73\%) internal sofa - sofa perpendicular to the front façade, 4 with (14\%) internal sofa - sofa in parallel to the front façade, 3 with $(10 \%)$ external sofa - sofa in parallel to the front façade, 1 with (3\%) external sofa - sofa perpendicular to the front façade. (Table 6) Internal sofa, facilitating air circulation inside the building, is present in $87 \%$ of all buildings. With this particular characteristic, these buildings are ecological for they contribute to passive climatization (Chandel, S. S., Sharma, V., Marwah, B. M., 2016).

Table 6. Spatial Organisation

\begin{tabular}{|c|c|c|}
\hline \multirow{15}{*}{ façade typology } & single storey-semi-basement-axial entrance & 2 \\
\hline & garden house- internal sofa with balcony & 1 \\
\hline & two storey-axial entrance-with projection & 5 \\
\hline & two storey-two entrance-with projection & 3 \\
\hline & $\begin{array}{l}\text { two storey-semi-axial inner entrance- with } \\
\text { projection }\end{array}$ & 2 \\
\hline & external sofa-single storey & 1 \\
\hline & two storey- axial entrance- with balcony & 4 \\
\hline & two storey- axial entrance- flat façade & 1 \\
\hline & garden house-internal sofa- with closed balcony & 1 \\
\hline & garden house-internal sofa-with balcony & 2 \\
\hline & two storey-axial entrance-no projection & 2 \\
\hline & $\begin{array}{l}\text { two storey-two entrance-closed cihannuma } \\
\text { (octagonal shaped gazebo) }\end{array}$ & 1 \\
\hline & garden house-external sofa- single storey & 2 \\
\hline & one storey-semi-basement-axial entrance & 2 \\
\hline & $\begin{array}{l}\text { two storey -semi-axial inner entrance-no } \\
\text { projection }\end{array}$ & 1 \\
\hline
\end{tabular}

Out of all 30 buildings under examination, 15 were found to have different façade typologies.

\section{Building envelope}

Out of a total of 30 buildings under examination; 22 (73\%) had spaces opening up to adjacent walls, while $8(27 \%)$ had spaces opening up to facing walls. (Figure 15) Since they facilitate airflow inside the building and help more spaces with ventilation, buildings with spaces opening up to adjacent walls are ecological. According to present findings, $73 \%$ percent of all buildings are ecological in this respect.

\section{Selection of materials}

Out of all 30 buildings under examination, recycling was possible for the materials used in 28 (93\%), while it was not possible for those used in 2 (7\%). Materials of 19 buildings (63\%) were re-usable; materials of 11 (37\%) buildings were not re-usable. 29 buildings (97\%) were constructed using local materials, while one building (3\%) was constructed with non-local materials. (Figure 15) According to present findings, since $93 \%$ of all buildings was constructed using recyclable materials, they are ecological in this respect. Since $63 \%$ of all buildings was constructed using re-usable materials, they are ecological in this 
respect. Since $97 \%$ of buildings were constructed using local materials, they are ecological in this respect for they comply with the multi-criteria and life-cycle approaches in eco-design (Bovea, M.D., Pérez-Belis, V., 2012).

\section{Use of renewable energy sources}

None of the 30 buildings under examination generated power using solar or wind power. Thus, the buildings are not ecological on this aspect. The use of solar and wind energy has been questioned actively under this article.

\section{Sanitary installation and circulation systems}

None of the 30 buildings under examination had rainwater usage or waste recycling/re-usage. Thus, the buildings are not ecological on this aspect.

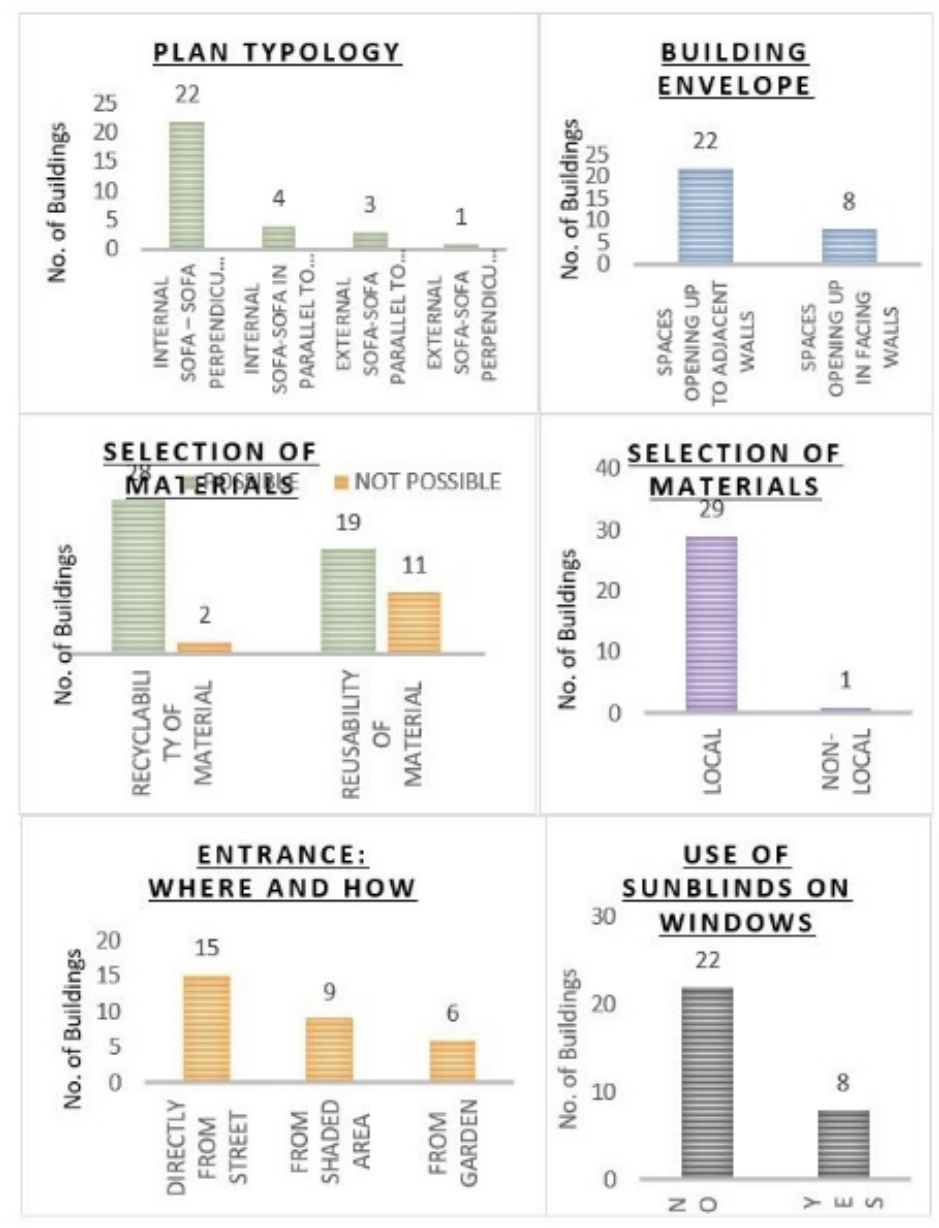

Figure 15. Findings

\section{Use of Sunblind on Windows}

$8(27 \%)$ out of a total of 30 buildings in this study have sunblind elements on their windows, 22 had (73\%) none. (Figure 15) The 27\% with sunblind elements are ecological from this point of view because sunblind elements control the harmful rays of sun. 


\section{Building Entrance: Where and How}

Out of all 30 buildings under examination, 15 have (50\%) direct entrance from street, 9 have (30\%) entrance from a shaded area, 6 have (20\%) entrance from the garden. (Figure 15) When building entrances are from shaded areas or gardens, they help circulate the cool air in those areas into the building, naturally decreasing the building heat. From this point of view, the $30 \%$ with shaded area entrance and the $20 \%$ with garden entrance are ecological buildings.

\section{CONCLUSION}

The traditional Mersin houses typically have a compact texture, and they have been affected by topography, culture, economical level of dwellings as well as climatic conditions. The traditional houses, which were built in an era where today's modern construction systems were not developed, available material variety was limited, technological means were inadequate and technical staff were few and far between, environmentally friendly, in harmony with the nature and held ecological value. It can be presumed that these vernacular characteristics generate eco-design benefits because people who had lived in them but have recently moved into new buildings complained that the new buildings are not as comfortable as the traditional ones.

The city of Mersin evidently has the ecologically necessary climatic and natural richness. Spatial reflections of this natural richness are observable in the use of construction techniques, selection of materials, orientation, spatial organisation and vegetation pattern of traditional houses. Traditional Mersin houses are a group of structures that are in harmony with the existing fabric, reflect the cultural diversity of the city on spaces and have ecological value. Preservation of these buildings is important for the city for they are part of the history and memory of the city. During the case study, many of these buildings were observed to be abandoned and in a state of ruin and collapse due to lack of maintenance. Buildings that are constructed by ignoring the natural and cultural richness of Mersin and through disrespectful interventions in the nature and the environment are rapidly multiplying. Buildings should be designed with Mersin's climatic and natural richness in mind and on the basis of ecological criteria during design, application and utilisation stages. The study hopes to serve as a systematic reference to guide architects through ecologic design processes based on the ecological application in the dwelling texture of Mersin. The findings of this study qualify as a general understanding of the ecological value of the vernacular architecture and a contribution to the search for a more sustainable method of development in the future.

\section{ACKNOWLEDGEMENTS/NOTES}

This study was presented as a paper during the XIII. Forum Internazionale di Studio, Heritage and Technology, Mind Knowledge Experience, Aversa conference, under the title "Analysis of Ecological 
Criteria for Traditional Housing and Its Adaptation to New Housing Design", and was expanded into journal article form.

Moving cases have been developed based on the master thesis entitled as "Investigating Ecological Aspects of the Traditional House Architecture in Mersin", by Ebubekir Gündoğdu under the supervision of Emel Birer in Istanbul Kultur University.

\section{FINANCIAL DISCLOSURE}

The authors declared that this study has received no financial support.

\section{ETHICS COMMITTEE APPROVAL}

Ethics committee approval was not required for this article.

\section{LEGAL PUBLIC/PRIVATE PERMISSIONS}

In this research, the necessary permissions were obtained from the relevant participants (individuals, institutions, and organizations) during the survey and in-depth interviews.

\section{REFERENCES}

Adıyeke, N., Adıyeke, N. (2004). Modernleşmenin Doğurduğu Kent: Mersin. Sırtı Dağ, Yüzü Deniz: Mersin, Yapı Kredi Yayınları, Prep. Filiz Özdem, İstanbul, 69-89.

Akdeniz Kent Araştırmaları Merkezi Raporu, (2005), MEÜ Mimarlık Fakültesi, Mersin Kültür Envanteri: Kentsel Kültür Varlıkları Belgeleme Projesi 1, Selim Ofset.

Akkaya, Y. (2004). 19. Yüzyıldan 20. Yüzyıla Mersin Ekonomisi, Sırtı Dă̆, Yüzü Deniz: Mersin, (Hazırlayan: Filiz Özdem), Yapı Kredi Yayınları, İstanbul, 335.

Baran, M., M. Yıldırım, and A. Yılmaz, (2011). Evaluation of Ecological Design Strategies in Traditional Houses in Diyarbakir, Turkey, Journal of Cleaner Production 19.6-7: 609-619.

Bovea, M.D., Pérez-Belis, V., (2012). A Taxonomy of Ecodesign Tools for Integrating Environmental Requirements into the Product Design Process, Journal of Cleaner Production, 20: 61-71

Buldum, B., Külekçi M., K. (2008). Mersin İlinin Güneş Enerjisi Potansiyeli ve Mevcut Durumu, VII. Ulusal Temiz Enerji Sempozyumu, İstanbul.

Chandel, S. S., Sharma, V., Marwah, B. M. (2016). Review of Energy Efficient Features in Vernacular Architecture for Improving Indoor Thermal Comfort Conditions, Renewable and Sustainable Energy Reviews, 65, pp. 459-477

Crowther, R.L., (1992). Ecologic Architecture. Butterworth, Boston.

Develi, Ş. (2001). Dünden Bugüne Mersin, 1836-1837, Mersin Ticaret ve Sanayi Odası Yayını, 143.

Dizdar, İ. (2009). Mübadele ve Konut Bağlamında Mersin İhsaniye Mahallesi, TÜBA-KED, no:7, 125.

Erdoğan, E., Yıldız, E.N. (2017). The Evaluation of Kayseri, Ağırnas 
Evaluation of Ecological Design Principles in Traditional Houses in Mersin

Traditional Houses in the Frame of Ecological Design, Eurasian Journal of Agricultural Research, VOL1/1, 64-72.

Gunewardene, N. (2016). Documentation of Vernacular Heritage in Architectural Education: 'Measured Drawing of Devala Buildings' with Level 1 Students of Architecture, University of Moratuwa, Sri Lanka, International Journal of Environmental Studies 73: 502-511. doi:10.1080/00207233.2016.1178983.

Gültekin, A., Bengu A, (2011). Ecological Building Design Criteria: A Case Study in Ankara. Gazi University Journal of Science 24.3, 605-616.

Kaptanoğlu, İ.Z., Mıhçığlu Bilgi, E. (2018). Conservation of Historic Sarlyer District in Istanbul: Improving Sustainability and Energy Efficiency of A Bosphorus Village, Megaron, v.4, 1.

Karahan, F., Davardoust, S., (2020). Evaluation of Vernacular Architecture of Uzundere District (Architectural Typology And Physical Form of Building) in Relation To Ecological Sustainable Development, Journal of Asian Architecture and Building Engineering, DOI: 10.1080/13467581.2020.1758108

Karahan, E. Ergöz. (2017). Sustainability of Traditional and Contemporary Housing and Household Lifestyles: Case of Osmaneli//Geleneksel ve Günümüz Konutunda Sürdürülebilirlik ve Yaşam Alışkanlıkları: Osmaneli Örneği, Megaron 12.3: 497.

Karaosman, S. (2008), Vernacular Design as the Teaching Tool of the Ecological Architecture, Designtrain Congress, Trailer: II, Designing Design Education, Modern Education in Architectural Design Basics, 5-7 Haziran 2008, Amsterdam, Hollanda

Kırbaş, B., Hızlı, N. (2016). Learning from Vernacular Architecture: Ecological Solutions in Traditional Erzurum Houses, Procedia - Social and Behavioural Sciences 216 (2016) 788 - 799.

Krusche, P., Althaus, D., Gabriel, I., (1982). Okologisches Baunen, Herausgegeben vom Umweltbundesamt, Bauwerlag GmblH, Wiesbaden und Berlin, 22.

Li, Z., (2006). A New Life Cycle Impact Assessment Approach for Buildings, Building and Environment, Elsevier Ltd.

Lyle, J.T. (1985). Design for Human Ecosystems, Van Nostrand Reinhold Company, New York, 183-192.

Mazouz, S., Zarouala, M. S. (2013). The Derivaton and Re-Use of Vernacular Urban Space Concepts, Architectural Science Review, 42:1, pp. 3-13.

Oktay, D., (2002). Design with the Climate in Housing Environments: An Analysis in Northern Cyprus, Building and Environment Journal, 37 (2002) 1003-1012.

Sanchez, P.A.L., Medrano, F.J.S. (2015). Sustainable Architecture in the Traditional Rural Environment: Moratalla, Mileto, C., Vegas, F., Garcia, L., Cristini, V. (editörler), Vernacular Architecture: Towards a Sustainable Future, Londra, Taylor and Francis Group, s. 449-454.

Sayın, S. (2006), The Significance of the Use of Renewable Energy in our Country's Building Sector and the Opportunities of Utilizing of Solar 
Energy in Buildings (Yenilenebilir Enerjinin Ülkemiz Yapı Sektöründe Kullanımının Önemi ve Yapılarda Güneș Enerjisinden Yararlanma Olanakları), M.Sc. Thesis, Selçuk University Institute of Science and Technology, Konya, Turkey.

Sözen, İ., Koçlar Oral, G. (2019). Evaluation of Parameters Affecting Energy Efficiency of Vernacular Mardin Houses: a case study, Megaron, Yıldız Technical University, Faculty of Architecture E-Journal, V14, s:1.

Şen, D.E., R.M. Sarı, S. Özgen ve A. Sağsöz, (2010). Design Principles of Nature Friendly House in the Context of Vernacular Architecture of Eastern Blacksea Region, Research Journal of International Studies, sayı:17.

Tönük, S. (2001). Bina Tasarımında Ekoloji, İstanbul, Yıldız Teknik Üniversitesi Basım Yayın Merkezi, 50.

Toksöz, M.,(2006). Bir Coğrafya, Bir Ürün, Bir Bölge: 19. Yüzyılda Çukurova, Kebikeç İnsan Bilimleri İçin Kaynak Araştırmaları Dergisi, Sanat Kitabevi, Ankara, issue 21, 97-110.

TȘS, No: 318, s.365, h.no: 625, 25 Cemazeyilevvel 1298 (M. 25 Nisan 1881).

Ünlü, T.S., (2009). Bir İskeleden Liman Kentine Doğu Akdeniz'in Önemli Bir Limanı Olarak On Dokuzuncu Yüzyılın İkinci Yarısında Mersin'de Mekânsal Gelişim, Planlama Dergisi, V:3-4, 5-26.

Van Der Ryn, S., Stuart, C., (1996). Ecological Design, Island Press.

Vallet, F., (2012). Using Eco-design Tools: An overview of experts' practices, Design Studies, 34.3, pp. 345-377

Yenişehirlioğlu, F. Müderrisoğlu, F. Alp, S. (1965). Mersin Evleri, T.C. Kültür Bakanlığı Yayınları, Ankara.

Yenișehirlioğlu, F.Ç (2004). Mersin Evleri, Sırtı Dağ, Yüzü Deniz: Mersin, Prep: Filiz Özdem, Yapı Kredi Yayınları, First Edition, İstanbul, 177-189.

Yenişehirlioğlu, F., Özveren, E., Ünlü T.S. (Editors) (2019), Eastern Mediterranean Port Cities, A Study of Mersin, Turkey From Antiquity to Modernity, ISSN 2365-757X XispiThe Urban Book Series, Springer, pp,5.

Zorlu, T., Faiz, S., (2012). Çevre Duyarlı Mimarlık, Mimarlık Dergisi, Sayı: 367.

URL 1:https://www.saglik.gov.tr/TR,11472/tcanayasasi-56madde.html date accessed: 12.06.2015.

URL2:https://www.mgm.gov.tr/veridegerlendirme/il-ve-ilceleristatistik.aspx?k=A\&m=MERSIN) date accessed: 12.11.2020

\section{Resume}

Ebubekir Gündoğdu currently works at Istanbul Metropolitan Municipality as an architect He received his M.Arch in architecture from Istanbul Kültür University.

Emel Birer currently works at İstanbul Kültür University, Department of Architecture, as a Professor. She received her M.Arch and Ph.d in architecture from Ylldiz Technical University. 